\title{
Beijing+20 Afghanistan Civil Society Progress Report
}

\author{
A Review of the Implementation of the Beijing Platform for Action
}

February 2015

Afghan Women's Network

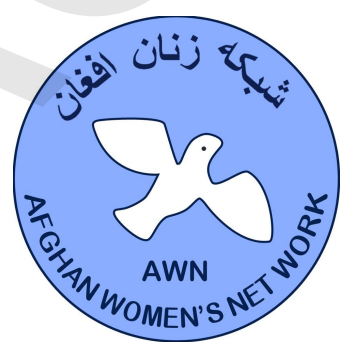




\section{Acknowledgements}

\section{Researchers}

AWN's Monitoring and Research Unit consisting of Hasibulla Faizi and Abdul Wasay Zarbi, are responsible for this research with support from AWN's Hotline and Law department staff.

This report was authored by Melike Karlidag.

\section{About AWN:}

The Afghan Women's Network (AWN) is a non-partisan, non-profit network of women that serves as an umbrella organization for $123 \mathrm{NGO}$ members, and 5,000 individual members who are committed to support the women of Afghanistan. AWN has offices in Kabul, Herat and Jalalabad and works through local partners in several Afghan provinces. Primary concerns for AWN are issues related to: gender-based violence, youth empowerment and girl's education. The network also represents and promotes the views of Afghan women in political and social arenas through advocacy and by challenging Afghanistan's leaders to enforce legislative reforms for the protection of women's rights.

For more information, see: www.awn-af.net Contact: director@awn-af.net

Special thanks are owed to the representatives of international organizations, embassies, the Government of Afghanistan and Afghan civil society that participated in the research as key informants.

Key informants that contributed with their knowledge represent the following entities (in alphabetical order): Afghan Judiciary (Judges), Afghan Women Skills Development Center (AWSDC), Afghanistan, Civil Society Forum Organization (ACSFO), Australian Department of Foreign Affairs and Trade (DFAT), AWN (Board and Founding Members), CARE International, Civil Society and Human Rights Network (CSHRN), Cordaid, Heinrich Böll Stiftung, Inclusive security, Kabul University, Legal and Cultural Services for Afghan Women and Children (LCSAWC), Medica Afghanistan, Ministry of Economy (MoE), Ministry of Finance (MoF), Ministry of Foreign Affairs (MoFA), Ministry of Labor, Social Affairs, Martyrs and Disabled (MoLSAMD), Ministry of Women's Affairs (MoWA), Qanoon Ghokhtana, Sanayee Development Organization (SDO), The Embassy of Canada to Afghanistan, The High Peace Council (HPC), The Parliament of Afghanistan, Women and Children Legal Research Foundation (WCLRF).

AWN would like to express its sincere appreciation to all the Afghan women and men in the provinces that took part in the survey.

AWN also thanks Cordaid and Global Network for Women Peacebuilders (GNWP) for the their constructive feedback on the earlier drafts of this report. 


\section{List of Abbreviations}

$\begin{array}{ll}\text { ANDS } & \text { Afghanistan National Development Strategy } \\ \text { ANP } & \text { Afghan National Police } \\ \text { AWN } & \text { Afghan Women's Network } \\ \text { BPfA } & \text { Beijing Declaration and Platform for Action } \\ \text { BPHS } & \text { Basic Package of Health Services } \\ \text { CSW } & \text { Commission on the Status of Women } \\ \text { EPHS } & \text { Essential Package of Hospital Services } \\ \text { EVAW } & \text { Elimination of Violence against Women } \\ \text { HPC } & \text { High Peace Council } \\ \text { MRU } & \text { Monitoring and Research Unit } \\ \text { NAP } & \text { National Action Plan } \\ \text { NAPWA } & \text { National Action Plan for the Women of Afghanistan } \\ \text { NRVA } & \text { National Risk and Vulnerability Assessment } \\ \text { PPC } & \text { Provincial Peace Council } \\ \text { UNSCR } & \text { United Nations Security Council Resolution } \\ \text { USAID } & \text { US Agency for International Development } \\ \text { WLSP } & \text { Women's Legal and Social Protection } \\ \text { WPPL } & \text { Women's Political Participation and Leadership } \\ \text { WPS } & \text { Women, Peace and Security }\end{array}$




\section{Table of Contents}

Executive Summary 1

Introduction 2

$\begin{array}{ll}\text { Objectives } & 2\end{array}$

Methodology 3

Scope of Study 3

Research Tools 3

Sample Size and Geographic Scope of Survey $\quad 4$

Limitations $\quad 5$

Demographic Information About Survey Respondents 6

Women's Political Participation and Leadership 8

Women's Participation in the Governance Structures $\quad 8$

Public Perceptions About Women's Role in the Governance of Afghanistan 10

Women, Peace and Security 15

The Impact of Armed Conflict on the Lives of Afghan Women and Girls 15

Women's Inclusion and Institutional Representation in the Afghan Peace Process 16

$\begin{array}{ll}\text { Public Perceptions About Women and Peace and Afghanistan } & 17\end{array}$

Women's Legal and Social Protection 21

$\begin{array}{ll}\text { Access to Justice and Accountability in Afghanistan } & 21\end{array}$

Public Perceptions About Women's Rights and Access to Justice 23

Women's Social Protection and Participation in the Workforce 27

Public Perceptions About Women's Access to Services 29

Conclusion 32

Recommendations 34

References $\quad 36$ 


\section{Executive Summary}

This report has been produced to inform the discussions that will take place during the 59th session of the Commission on the Status of Women (CSW59), planned to take place in March 2015. It reviews the progress that has been achieved in Afghanistan against some of the strategic objectives of the Beijing Declaration and Platform for Action (BPfA), twenty years after the plan's adoption, with focus on the achievements and challenges in the three strategic areas of AWN:

- Women's Political Participation and Leadership

- Women, Peace and Security

- Women's Legal and Social Protection

The following are the specific objectives of the research:

- To inform Afghan and global policy makers about the progress that has been achieved against key targets to empower women;

- To identify challenges and gaps that need to be addressed to make further progress;

- To provide practical recommendations to increase the effectiveness of policy implementation.

A combined methodology including a countrywide survey, desk review and key informant interviews with relevant organizations and government officials was used in the research. ${ }^{1} \mathrm{~A}$ total of 1,396 Afghan women and man participated in the survey across twenty-five provinces of Afghanistan between December 2014 and January 2015.

Notable progress has been achieved with regard to women's rights and empowerment in the past thirteen years, since Afghanistan began its democratization process in late 2001. Presently, women hold close to 30 percent of the seats in the parliament, they serve as ministers and participate in decision-making at the national, subnational and local levels. Women are also visible as justice and security sector officials. They take part in peace councils and work in the civil service. There is no denying that the women of Afghanistan have come a long way in their efforts to access some of their most critical civic rights. There are, however, many challenges that continue to impede the empowerment of women. One such challenge is related to the practical implementation of several of Afghanistan's key strategies and laws, such as the National Action Plan for the Women of Afghanistan (NAPWA) and the Elimination of Violence Against Women (EVAW) law, which have been ratified to ensure women's rights and protection. Moreover, many women that work in government offices are still excluded from participating in decision-making in a meaningful way. Other challenges include women's exclusion from the peace process and continued difficulties accessing social rights such as access to education and healthcare, mainly in rural Afghanistan where the majority of Afghans live.

\footnotetext{
${ }^{1}$ A full list of key informants is available in the acknowledgement, p. ii.
} 


\section{Introduction}

Afghanistan is considered one of the most difficult countries in the world to be a woman. Women continue to be highly vulnerable in a patriarchal society governed by state institutions that are weakened by decades of civil war. As part of the post-2001 democratization process, the women of Afghanistan gained numerous political, legal and social rights. Women's rights in Afghanistan has come a long way over the past thirteen years, however, the results have not been achieved without great effort by women's rights organizations, activists, civil society organizations and women political leaders, who have tirelessly promoted and defended the rights of women in Afghanistan.

This report has been produced to inform the discussions that will take place during the 59th session of the Commission on the Status of Women (CSW59), which will be held from 9 to 20 March 2015 at the United Nations Headquarters in New York. The focus of this report is to review the progress that has been achieved in Afghanistan against some of the strategic objectives of the Beijing Declaration and Platform for Action (BPfA) adopted in 1995. The topics discussed in this report include the three strategic areas of Afghan Women's Network, namely:

- Women's Political Participation and Leadership

- Women, Peace and Security

- Women's Legal and Social Protection

There is a pressing need to renew the commitment for gender equality and women's rights by decision-makers in Afghanistan. The approaching Beijing+20 session of CSW59 offers an opportunity to reinforce existing policy frameworks and to turn these into actionable, time-bound and measurable strategies that achieve meaningful advancement in women's empowerment in all aspects of society. The newly elected National Unity Government of Afghanistan needs to show that its verbal commitment will translate into real and significant change by for example allocating sufficient financial and human resources to ensure a successful gender mainstreaming.

\section{Objectives}

The following are the specific objectives of the research:

- To inform Afghan and global policy makers about the progress that has been achieved against key targets to empower women;

- To identify challenges and gaps that need to be addressed to make further progress;

- To provide practical recommendations to increase the effectiveness of policy implementation. 


\section{Methodology}

\section{Scope of Study}

The overall scope of the research has been guided by the three strategic areas of Afghan Women's Network, which guide the network's program activities. The three strategic areas include:

- Women's Political Participation and Leadership

- Women, Peace and Security

- Women's Legal and Social Protection

This research was undertaken between December 2014 and February 2015.

\section{Research Tools}

Three key research tools were used in this study. First, a comprehensive desk review was carried out to identify relevant previous research and publications. The desk review was guided by the following questions:

1. What progress has been achieved in the fields of Women's Political Participation and Leadership (WPPL), Women, Peace and Security (WPS) and Women's Legal and Social Protection (WLSP) in Afghanistan since 2001? ${ }^{2}$

2. How has the progress been achieved and what policies have been implemented?

3. What are the challenges that still remain and how can these challenges be addressed effectively?

Second, in-depth individual interviews with respondents from six international organizations and donors, ten Afghan civil society organizations and twelve Afghan government officials was carried out by AWN's Monitoring and Research Unit (MRU).

Finally, a comprehensive survey was undertaken across Afghanistan with support from AWN's regional offices. The survey questionnaire is limited to the three strategic areas of AWN. It was developed by the Monitoring and Evaluation Unit (MRU) of AWN, informed by the existing datasets that have been collected through similar research processes for specific projects in the relevant fields.

The survey questionnaire and interviews guides were developed by the MRU, consisting of professionals with extensive contextual knowledge and experience. Once the data arrived from

\footnotetext{
2 This study focuses on the post-2001 period of Afghanistan's history, as the country's democratization process began with the signing of the Bonn agreement in December 2001, shortly after the fall of the Taliban regime. Prior to 2001, the women of Afghanistan were deprived of their fundamental rights under the Taliban regime.
} 
the provinces, each survey was entered into online based software SurveyMonkey for the analysis and visualization of the data as presented in this report.

\section{Sample Size and Geographic Scope of Survey}

The survey data was collected through AWN's staff in the regional offices that travelled to nearby provinces to conduct the survey. A total of 1,396 Afghan women and man participated in the survey across twenty-five provinces of Afghanistan (See Map 1). Some provinces have fewer survey participants due to lack of resources and inability of surveyors to reach out to the populations. Roughly 70 percent of the surveys took place in the provincial capitals while the remaining 30 percent were undertaken in the rural areas. All surveys were conducted face to face.

\section{Map 1: Geographic coverage of survey}

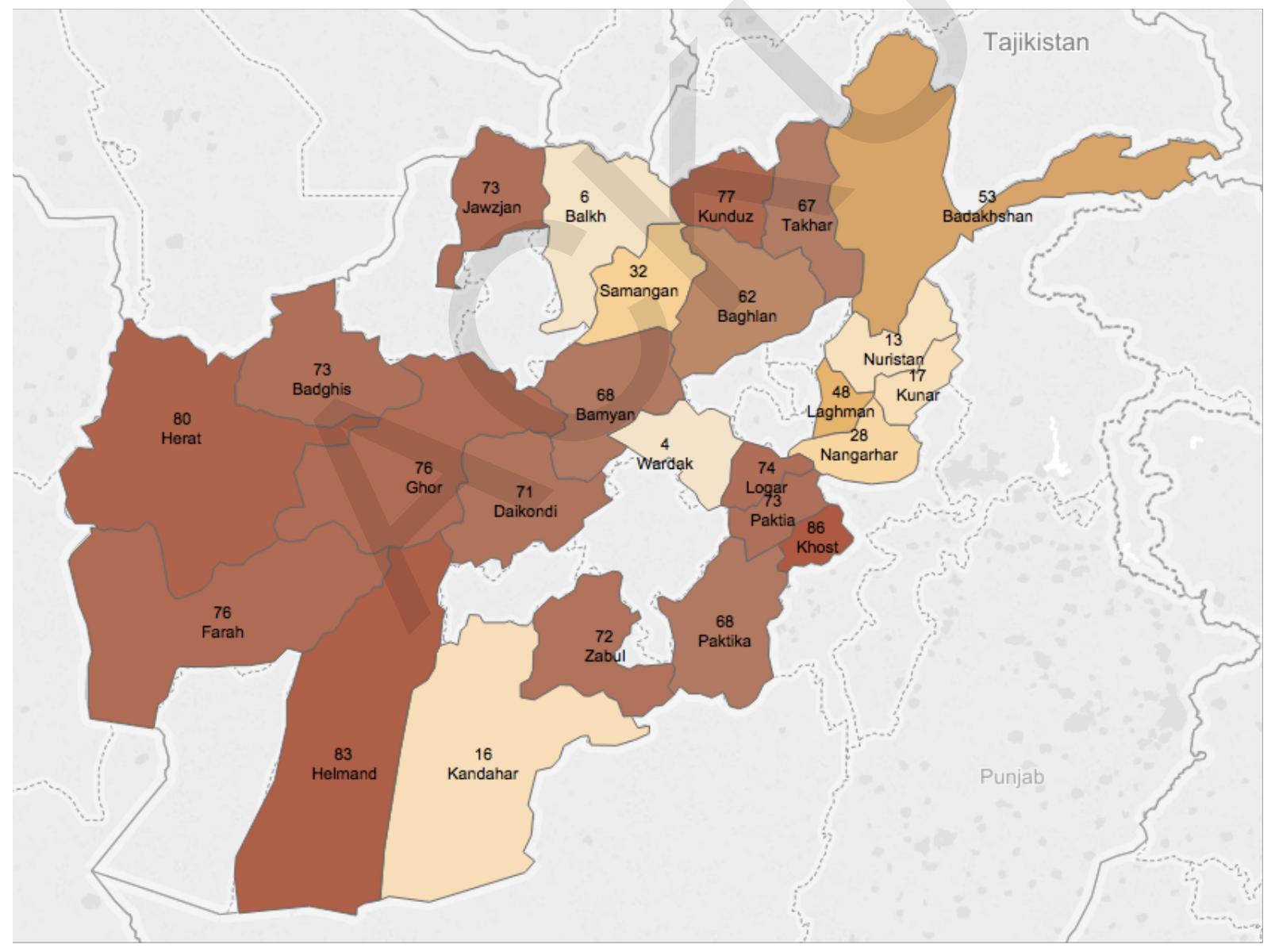




\section{Limitations}

Limitations encountered during the research are chiefly related to the data collection process. There were numerous obstacles that made it challenging to survey people in the provinces. First, a recent increase in insecurity hampered the mobility of the surveyors in the provinces, which made it difficult to reach some parts of the country. Second, the insecurity in the provinces also made it challenging to approach the populations since people were reluctant to share their views openly with the surveyors. Third, it has been difficult to schedule interviews with government officials as some of them have been unresponsive when the MRU researchers reached out to them. Such challenges led to unanticipated research delays. 


\section{Demographic Information About Survey Respondents}

\section{Figure 1: Gender composition of respondents}

Answered: 1,396

skipped: 0

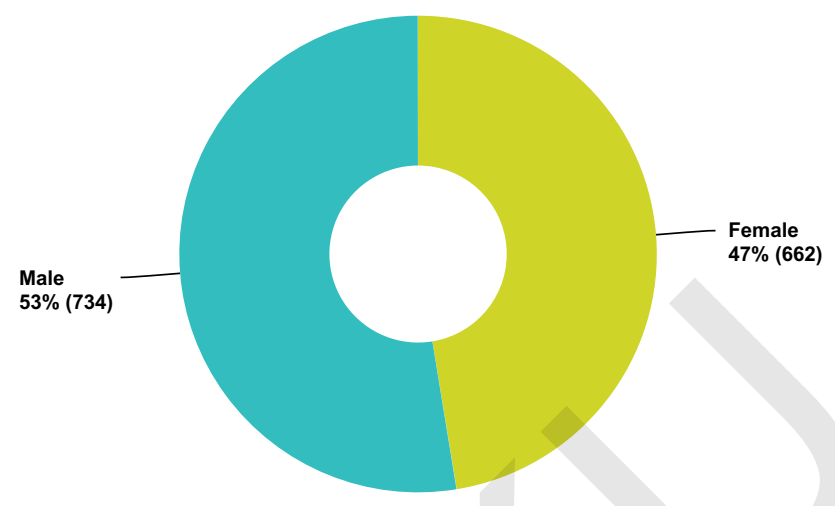

As seen in Figure 1, the gender composition of the survey respondents is relatively equal. Out of 1,396 individuals that participated across twenty-five provinces, 47 percent were women and 53 percent were men.

Table 1: Age Groups of Survey Participants

\begin{tabular}{|l|r|r|}
\hline Age Groups & Total & \\
\hline $13-22$ & 247 & $17.69 \%$ \\
\hline $23-32$ & 528 & $37.82 \%$ \\
\hline $33-42$ & 370 & $26.50 \%$ \\
\hline $43-52$ & 173 & $12.39 \%$ \\
\hline $53-62$ & 55 & $3.94 \%$ \\
\hline $63-72$ & 21 & $1.50 \%$ \\
\hline $73-82$ & 2 & $0.14 \%$ \\
\hline Grand Total & 1396 & $100 \%$ \\
\hline
\end{tabular}

Approximately 80 percent of the survey respondents are between 13-42 years old. This indicates that the bulk of the survey participants represent a relatively young population. This is in line with the actual demographic age composition of the Afghan population. According to a 2010 national survey, more than 80 percent of the Afghan population is estimated as being below 40 years old. ${ }^{3}$

${ }^{3}$ Afghan Public Health Institute (November 2011), Afghanistan Mortality Survey 2010, page 19, available at: http://dhsprogram.com/ publications/publication-fr248-other-final-reports.cfm 
Figure 2: Profession of respondents

Answered: 1,396

Skipped: 0

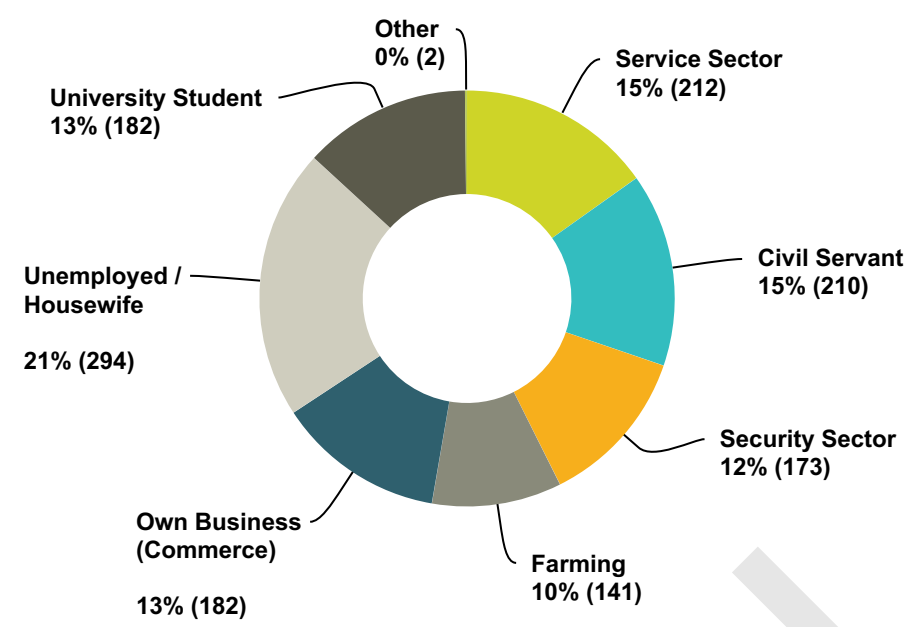

As shown by Figure 2, the survey sample consists of diverse groups inducing farmers, housewives and the unemployed, security sector officials including male and female police officers, civil servants in government offices, university students, people that own their own business, and service sector professionals in the health and education sectors mainly.

Figure 3: Education level of respondents

Answered: 1,396

Skipped: 0

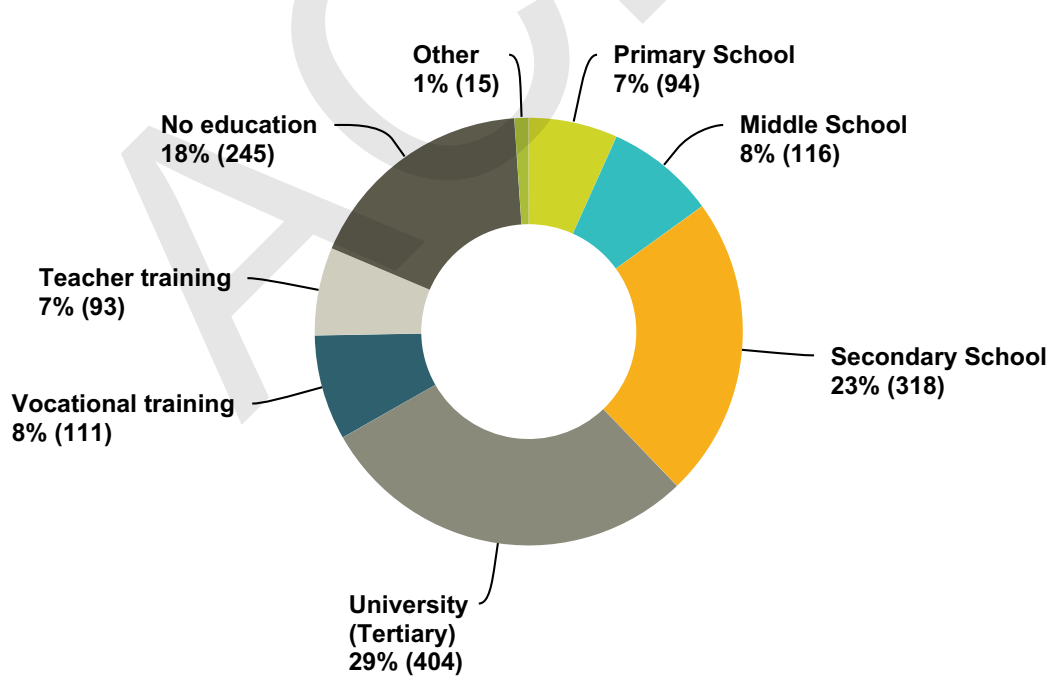

Similar to the professional diversity, the survey sample also includes 1,396 people from different educational backgrounds. While 29 percent of the respondents were either university students or had a post-secondary education, 18 percent of the population was people who had not been to school at all. Similarly, 23 percent had secondary education while 15 percent had primary and middle school education. Another 15 percent had vocational trainings and teacher training qualifications (Figure 3). 


\section{Women's Political Participation and Leadership}

\section{Women's Participation in the Governance Structures}

Significant progress in women's political participation has been achieved in the past thirteen years since late 2001, when Afghanistan began its democratization process after the fall of the Taliban regime. Today, 68 out of 249 seats (28 percent) of the Lower House and 28 out of 102 seats (27 percent) of the Upper House of the Parliament are reserved for women. At the provincial level, 25 percent of the 420 seats in the 2009 elections were reserved for women. The quota system of the electoral law has ensured women's representation in governance structures at the national and subnational levels since the first elections in 2004 and 2005. Correspondingly, three female ministers served in the cabinets of president Karzai between 2004-2006 and 2010-2014. ${ }^{4}$ Further, women have increased their access to work in the civil service as they currently hold 19 percent of the national positions. Women also hold more than 30 percent of the Community Development Council seats at the local level. ${ }^{5}$

Despite the many important steps that have been taken in the right direction, many challenges still remain regarding women's political empowerment and inclusion in Afghanistan. In May 2013, as a result of a push by conservative forces, the Lower House of Parliament approved a revised electoral law, which reduced the 25 percent quota of the provincial council seats to 20 percent. $^{6}$ This change has significantly decreased women's chances of winning seats and influencing the decision-making in future provincial councils. Further, the 19 percent representation in the civil service is considerably below the $\mathbf{3 0}$ percent target as stipulated in the National Action Plan for the Women of Afghanistan (NAPWA), to which the government of Afghanistan reaffirmed its commitment during the Tokyo Conference of July 2012. ${ }^{7}$

During the 2014 presidential elections, women represented 38 percent of the total voter turnout. ${ }^{8}$ Women's electoral turnout is generally considered a major stepping-stone to the democratic transition of Afghanistan. The two presidential candidates Ashraf Ghani and Abdullah Abdullah both signed a petition prepared by AWN, confirming their commitment to appoint women to at least 25 percent of all seats in the cabinet, local government, ministries, legal entities and several

\footnotetext{
${ }^{4}$ Katzman, K (November 30, 2012), Afghanistan: Politics, Elections and Government Performance, CRS Report for Congress, available at: http:// www.au.af.mil/au/awc/awcgate/crs/rs21922.pdf

${ }^{5}$ Katzman, K (January 12, 2015), Afghanistan: Politics, Elections and Government Performance, CRS Report for Congress, available at: https:// www.fas.org/sgp/crs/row/RS21922.pdf

${ }^{6}$ Radio Free Europe / Radio Liberty (August 2014), Protections for Women Under Threat in Afghanistan, available at: http://www.rferl.org/ content/afghanistan-women-gender-legislature-quota/25026221.html

${ }^{7}$ See Katzman (2015) and The Tokyo Declaration (July 8, 2012), available at: http://president.gov.af/Content/Media/Documents/ TokyoDeclaration-FinalEnglish87201218653461553325325.pdf

${ }^{8}$ National Democratic Institute (June 16, 2014), Preliminary Statement of the National Democratic Institute's Election Mission for Afghanistan's 2014 Presidential Runoff Election, available at: https://www.ndi.org/files/NDI-Afghanistan-2014-EOM-Runoff-Preliminary-Statement-FINAL.pdf
} 
other important decision-making positions. Further, the two candidates committed to safeguarding the existing quotas for women's political participation while also promising to allocate funds for the implementation of two key policies, Afghanistan National Development Strategy (ANDS) and the National Action Plan for the Women of Afghanistan. ${ }^{9}$

Recent developments have indicated that these promises may be broken. During his campaign, President Ghani promised to appoint at least four female ministers in his new cabinet, should he be elected. However, in early 2015 only three female candidates were nominated for the ministries of higher education, information and culture and women's affairs. Yet, none of the female candidates were approved by the parliament. Further, two of these cabinet posts are traditionally considered as "women's posts", which is problematic in itself. Such developments have led to disillusionment among women's rights activist that demand higher representation. ${ }^{10}$

Other challenges that impact women's political participation include the security situation, especially in rural Afghanistan, the lack of political will to include women in decision-making in a meaningful way and the inability of women leaders to build political alliances to increase their influence in the decision-making. ${ }^{11}$ The insecurity in the rural parts of the country limits the mobility female politicians that are unable to campaign in rural parts of the country without taking major security risks. Several female political leaders have been physically targeted by armed opposition groups while traveling in the provinces. Some recent cases include the bomb attack that killed a female provincial council member in Nangarhar in February 2015, and another attack that wounded a female MP while traveling in a convoy in November 2014. ${ }^{12}$ Although there are several important policies and strategies in place to increase women's political participation, putting policies into practice remains a challenge. Strategies such as ANDS and NAPWA continue to be poorly implemented at the local and subnational levels, mainly as a result of limited funding allocation and weak capacity among local institutions and individuals, responsible for the implementation. ${ }^{13}$

Another key challenge to women's political empowerment is the limited ability of female political leaders to influence decision-making processes. Women that participate in management meetings at the ministries often participate as bystanders and are unable to contribute actively. ${ }^{14}$

\footnotetext{
${ }^{9}$ Afghan Women's Six Point Petition (June 2014), available at: https://www.cordaid.org/media/medialibrary/2014/06/ Afghan Womens Six Point Petition_1.pdf

10 The Guardian (February 3, 2015), Afghan women protest at absence of female ministers in new cabinet, available at: http:// www.theguardian.com/global-development/2015/feb/03/afghan-women-protest-absence-female-ministers-new-cabinet

${ }^{11}$ These challenges were identified through key informant interviews with relevant international and national organizations in Afghanistan. Further, previous research findings from AWN's interviews with leading female Member's of Parliament (MPs) confirm these challenges.

12 See for example: Reuters (February 16, 2015), Bomb attack in eastern Afghanistan kills female politician, available at: http://uk.reuters.com/ article/2015/02/16/uk-afghanistan-women-idUKKBNOLK1EB20150216 and BBC (November 16, 2014), Afghan woman MP survives car attack, available at: http://www.bbc.com/news/world-asia-30073189

13 AREU (September 2013), Women's Rights, Gender Equality, and Transition: Securing gains, moving forward, available at: http://www.areu.org.af/ Uploads/EditionPdfs/women\%20and\%20Transition.pdf

${ }^{14}$ AWN interviews with women decision-makers and female MPs (December 2014)
} 


\section{Public Perceptions About Women's Role in the Governance of Afghanistan}

Figure 4: Acceptance of women's participation in the governance of Afghanistan - general and by gender

Question: Should Afghan women be politically more active and play a bigger role in the governance of Afghanistan?

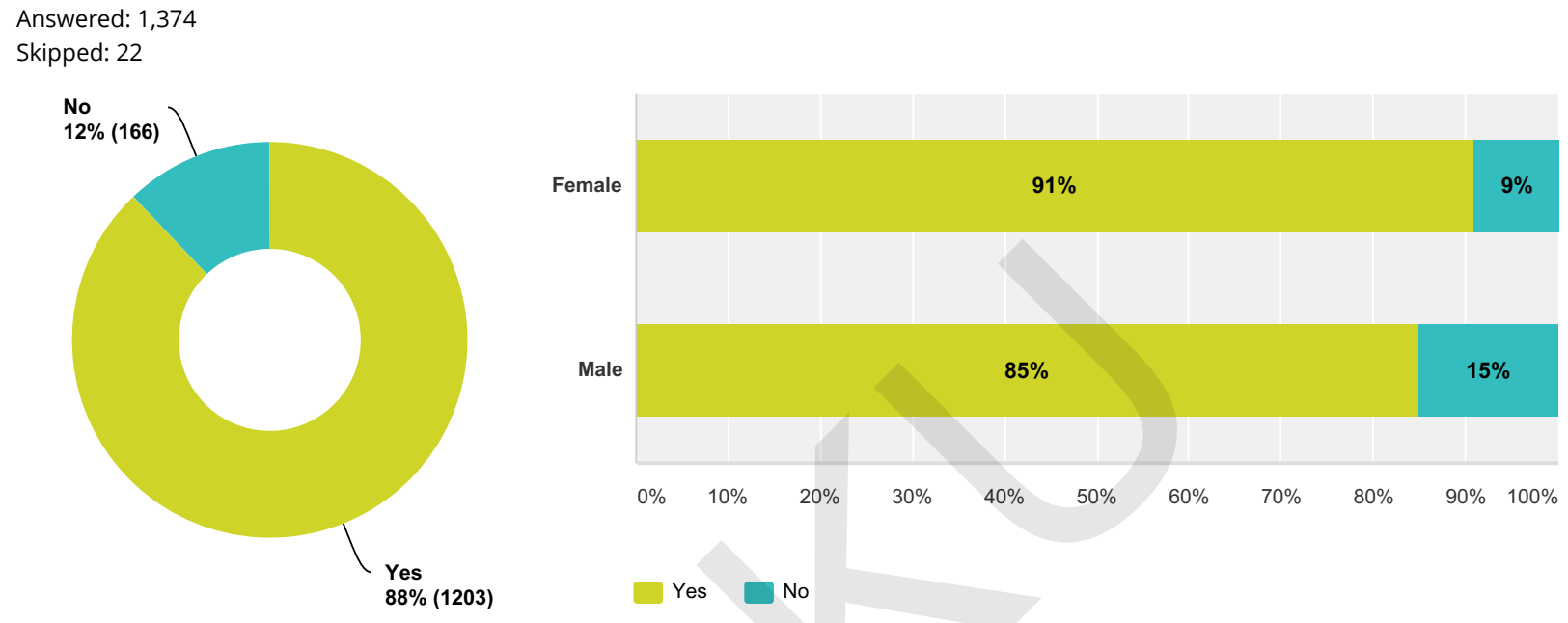

According to 88 percent of the 1,374 survey participants, Afghan women should play a more active role in the governance of Afghanistan. There is no notable change between the perceptions of women and men. It appears both genders agree that Afghan women should participate more in the decision-making processes in the government. 
Figure 5: Afghan women in politics - general

Question: How do you think the Afghan people perceive Afghan women in politics? Please choose the statement that you think represents reality most accurately.

Answered: 1,373

Skipped: 23

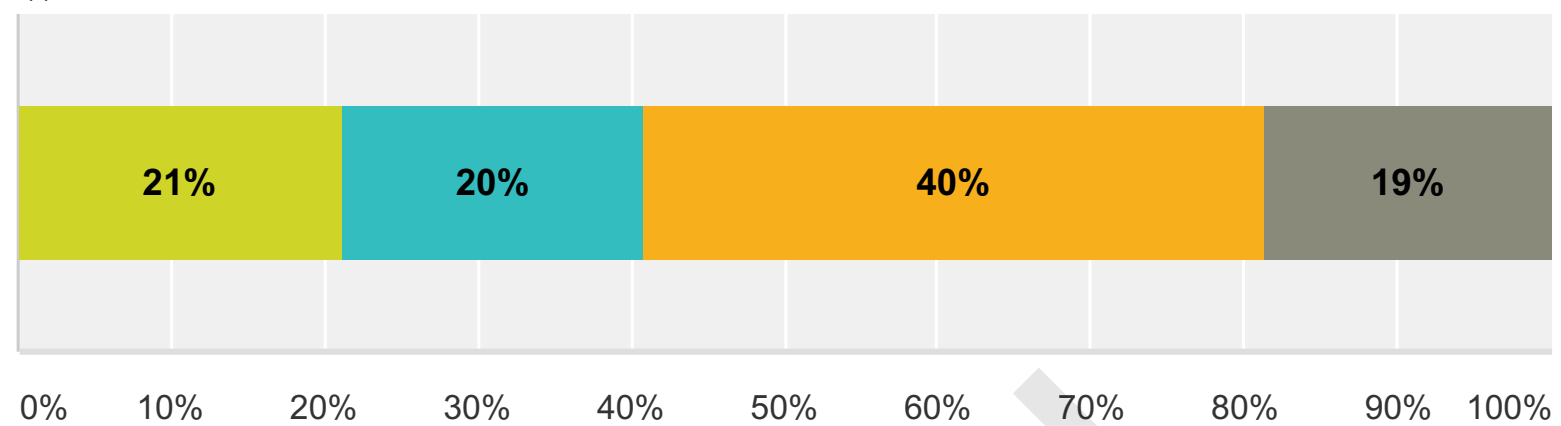

Women have no place in politics and it is inappropriate for women to have a public life

Women are not educated enough and do not have the capacity to lead the country

Women should be more encouraged to participate in politics

Women are just as capable as men and should be offered more opportunities

To get an overall understanding about the Afghan perception of women's engagement in politics, the survey participants were asked a multiple choice question about how they thought the Afghan people perceived women's political participation. About 40 percent of the respondents thought that the Afghan people would want women to be more encouraged to take part in politics. Roughly 40 percent of the respondents thought that Afghan's generally suppose that women have no place in politics or that women are not educated enough and do not have the capacity to lead the country. Less than 20 percent replied that Afghan's perceive women and men equally capable in the governance of the country. 
Figure 6: The quota system for women in the parliament and provincial councils - by gender

Question: What is your opinion of the electoral law which reserves 20 percent of the provincial council seats and 27 percent of the Wolesi Jirga (Lower House of Parliament) seats for women? Please choose the statement that you agree with most.

Answered: 1,374

Skipped: 22

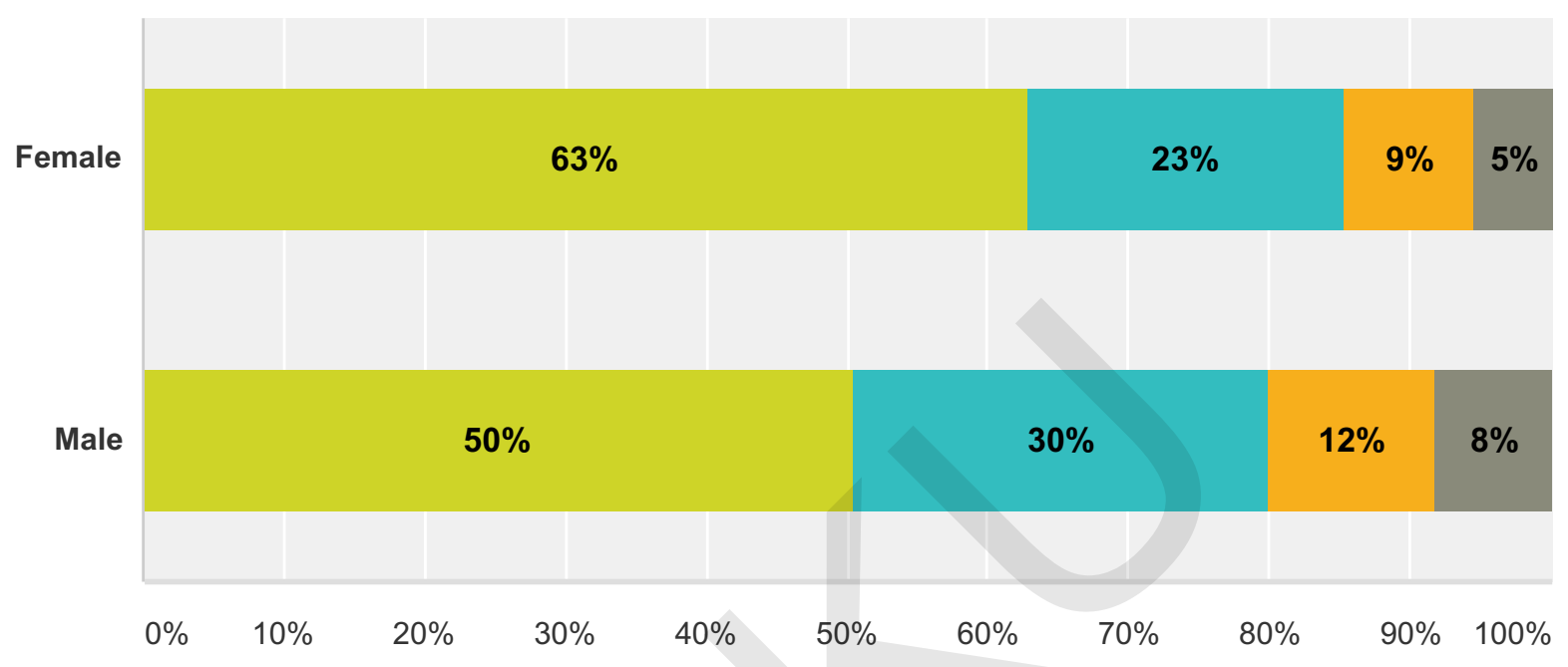

This is a low number and the percentage of women should increase

This is a fair number and should be preserved to safeguard women's representation

This is a too high percentage and women do not need to have so many seats

The quota system is inappropriate and should be removed altogether

Figure 6 indicates that, generally speaking, people in Afghanistan support the existing quota system for the parliamentary and provincial council elections. Fifty percent of the men and 63 percent of the women thought that the current quota is too low, and should be increased to give women more seats in the national and subnational governance structures. Further, 30 percent of the men and 23 percent of the women replied that the current number of seats reserved for women is fair and should be maintained to safeguard women's representation. About 20 percent of the male and 14 percent of the female respondents either thought that the quota was too generous or that the quota system was unnecessary and should be removed entirely.

Similarly, Figure 7 indicates that the majority of Afghan men and women think it is fair that a minimum of 30 percent of all ministerial job positions be filled by women, to increase their presence in the governance structures. However, when compared across the genders, more women than men seemed to be supporting this policy, as 48 percent of the male respondents thought this was an unfair approach and that ministries should hire based in qualifications only. 
Figure 7: The reservation of 30 percent of ministerial job positions for women - by gender

Question: According to the National Action Plan for the Women of Afghanistan (NAPWA), which is a strategy approved by the government, all ministries should make sure that at least 30 percent of all ministerial job positions must be filled by women. What is your opinion about this? Please choose one of the (two) options closest to your opinion.

Answered: 1,375

Skipped: 21

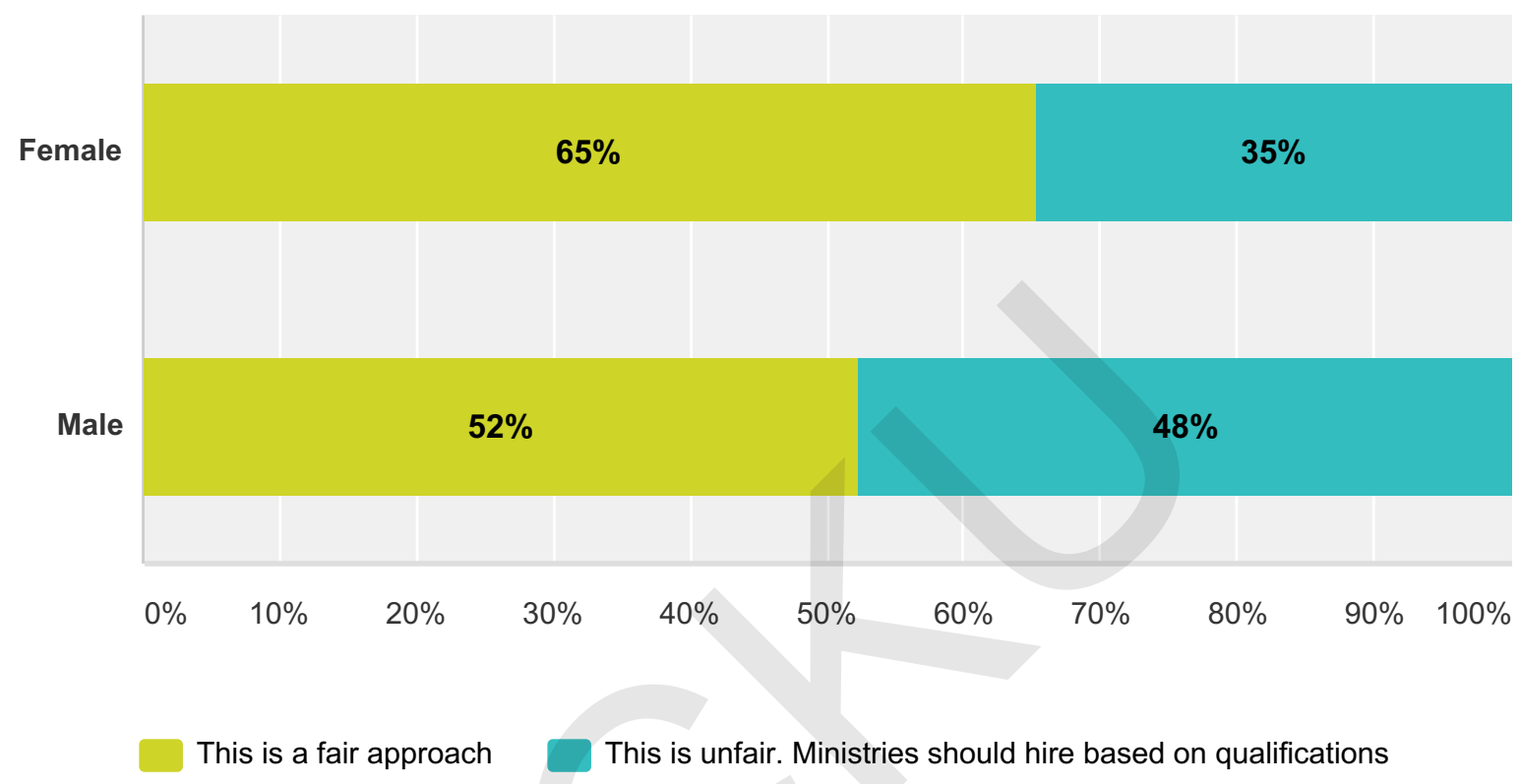

Figure 8 shows that the majority of survey participants believe that women and men have equal rights and duties before the law, while 15 percent of the women and 18 percent of the men replied that they did not think that women and men had the same rights and duties. A similar pattern is seen in Figure 9, which shows that the majority of the respondents feel that a woman's vote is equal to a man's and that women are as capable as men in determining who should lead Afghanistan. 


\section{Figure 8: Women's equal rights and duties before the law}

Question: According to the Afghan Constitution "the citizens of Afghanistan - whether man or woman - have equal rights and duties before the law". Do you agree with this definition?

Answered: 1,318

Skipped: 78

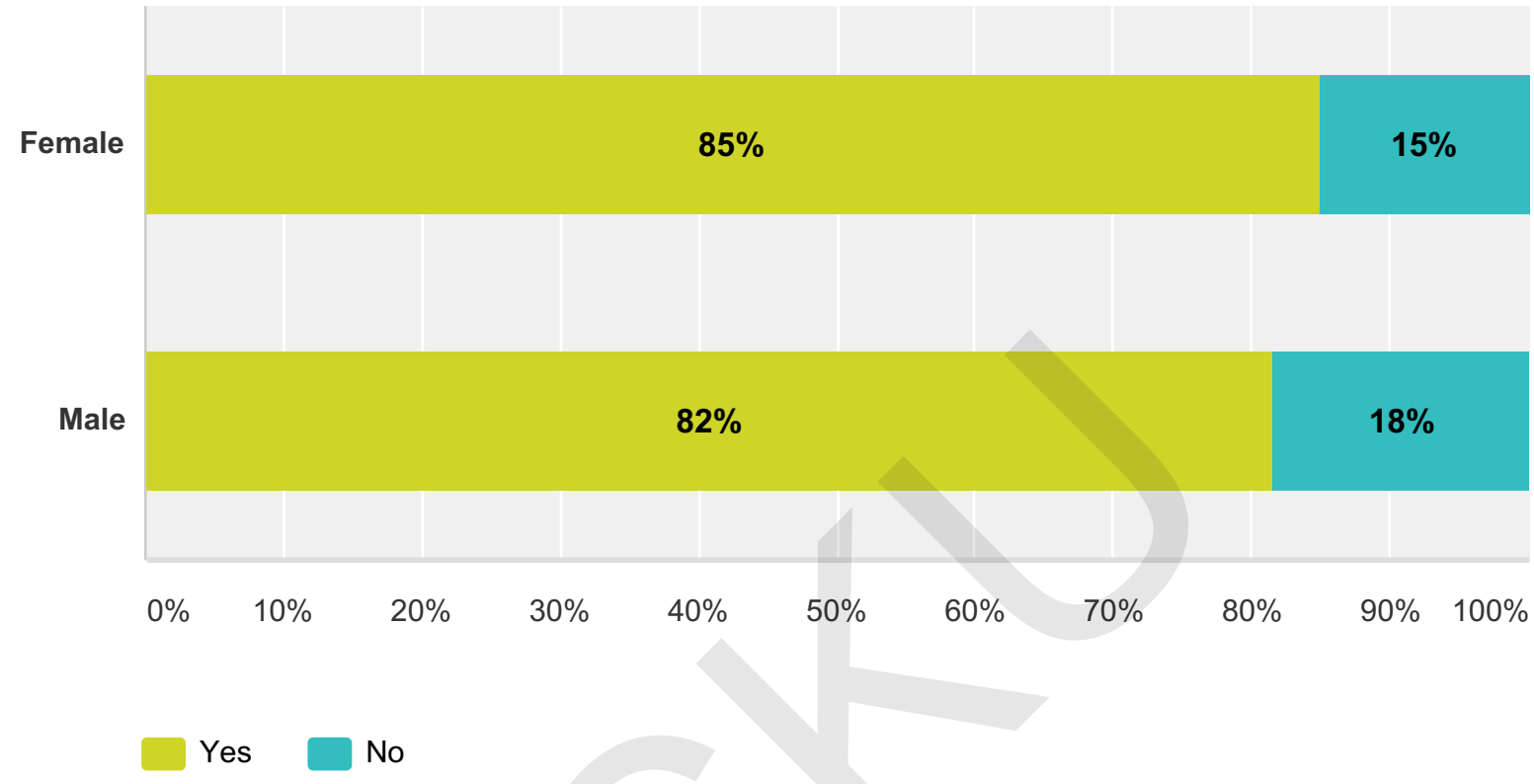

Figure 9: The importance of women's vote - general and by gender

Question: Do you think that an Afghan woman's vote is equal to an Afghan man's and that women are as capable as men in determining who would be the best leaders for Afghanistan?

Answered: 1,370

Skipped: 26

No

$22 \%$ (297)

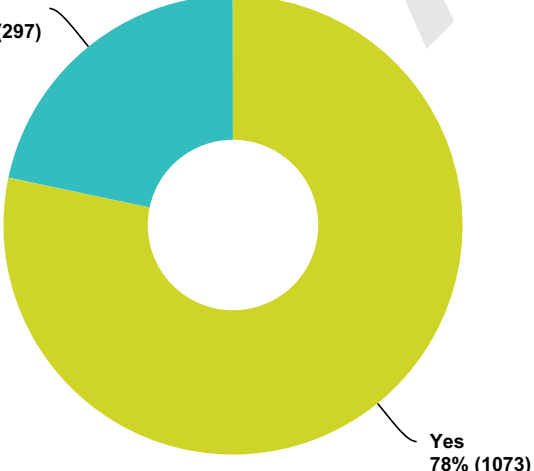

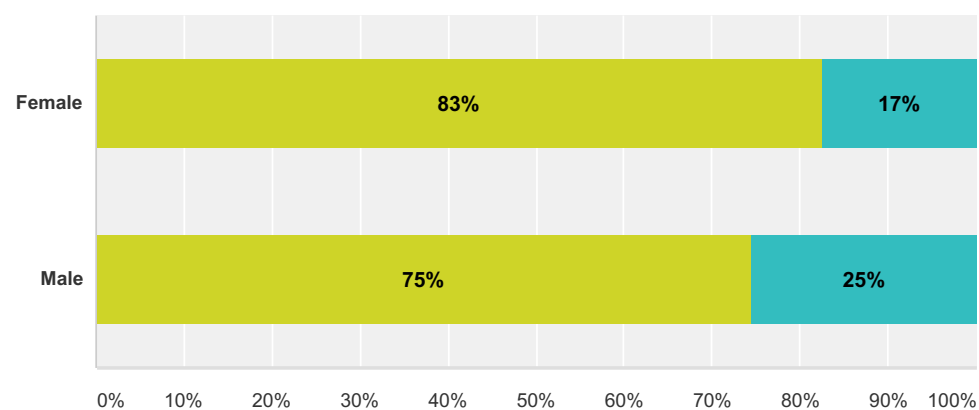

Yes No 


\section{Women, Peace and Security}

\section{The Impact of Armed Conflict on the Lives of Afghan Women and Girls}

Decades of conflict and an oppressive rule by the Taliban have had a devastating impact on the lives of Afghans as a people. However, as is the case with most conflicts, women and children suffer disproportionately as they are often the worst affected by conflict. After years of conflict between rival armed groups (1992-1996), systematic violence against women increased greatly. It was not uncommon for armed groups to rape and murder women in their homes. ${ }^{15}$ Further, as a result of the conflict, women and girls were often abducted and forced into marriages with commanders. ${ }^{16}$

The conflict in Afghanistan has also led to the deterioration of social institutions such as schools and health services, which has deprived women of access to education and healthcare. Moreover, during the years of the Taliban rule (1996-2001), the gross school enrollment of girls fell from 32 percent to 6.4 percent, as most girls' schools were closed due to the prohibition of girls' education. ${ }^{17}$

Women's access to healthcare was equally limited during the same period. The Taliban issued a decree prohibiting women from working, which forced many female health staff to leave their work. Although female health workers were later permitted to continue working by the Ministry of Public Health, women often chose not to return to work due to the risk of getting arrested by the religious police in the streets. In addition, male doctors and health staff were not permitted to treat women without the presence of a mahram ${ }^{18}$, and many widows and women in general did not have male relatives to accompany them. Even with a male chaperone, treatment was limited, since male doctors were not permitted to touch or see female patients' bodies. ${ }^{19}$

The lack of healthcare had adverse effects on the life expectancy Afghan women and girls. In 2005, four years after the fall of the Taliban regime, the maternal mortality rate was estimated as 1,600 fatalities per 100,000 live births. Similarly, the infant mortality rate was as high as 115 fatalities per 1,000 live births. By 2013, these figures had dropped to 327 and 74 respectively,

\footnotetext{
${ }^{15}$ Amnesty International Report 1995 - Afghanistan, 1 January 1995, available at: http://www.refworld.org/docid/3ae6a9fb18.html

${ }^{16}$ Cortright, D and Kirsten Wall (August 2012), Afghan Women Speak - Enhancing Security and Human Rights in Afghanistan, available at: http:// kroc.nd.edu/sites/default/files/Afghan_Women_Speak_Report.pdf

${ }^{17}$ Oxfam (February 2011), High Stakes - Girls' Education in Afghanistan, available at: http://www.oxfam.org/sites/www.oxfam.org/files/ afghanistan-girls-education-022411.pdf

${ }^{18}$ A mahram is a woman's husband or a close male relative that she would not be allowed to marry, such as a brother or a father.

19 Physicians for Human Rights (1998), The Taliban's War on Women, A Health and Human Rights Crisis in Afghanistan, available at: https:// www.law.georgetown.edu/rossrights/docs/reports/taliban.pdf
} 
mainly due to the efforts made by the international community and the Afghan government to increase women's access to health facilities. ${ }^{20}$ Comparably, the number of girls enrolled at schools had reached nearly 40 percent in 2013. This is a significant progress that has been achieved in the past thirteen years, considering that there were almost no girls attending school in $2001 .{ }^{21}$

\section{Women's Inclusion and Institutional Representation in the Afghan Peace Process}

The Afghan society is patriarchal and strongly rooted in customary values. Such values often reinforce the traditional views of gender roles in Afghanistan. It is, for example, generally assumed by the public that negotiations with the armed opposition should be led by male peace negotiators. This assumption often results in the exclusion of women from the peace process.

The UNSCR 1325 was adopted in October 2000. It recognizes the importance of including women in global peace processes, especially if a lasting peace is to be achieved. The UNSCR 1325 calls for the equal participation of women across all levels of peace building from the initial peace negotiations to the post-conflict reconstruction phase. ${ }^{22}$ The resolutions is applicable to all United Nations Member States, including the Government of Afghanistan, though its implementation has proven especially challenging in the Afghan context, mainly due to the prevalence of conflict that is continuing even today..$^{23}$

The High Peace Council (HPC), with its 31 Provincial Peace Councils (PPCs), is the main responsible body for carrying out negotiations with the armed opposition groups in Afghanistan. Out of the High Peace Council's 70 members, only nine are women. ${ }^{24}$ At the provincial level, there are a total 31 PPCs in 31 provinces with 25-30 members each. Among these 25-30 members, two to four are reported as being women. Women's role in the HPC and the PPCs are often considered as symbolic, without tangible contribution to the actual peace process. Women are often sidelined at the peace council meetings. These meetings are reported as being run by men and failing to pay enough attention to the needs and insights of women. ${ }^{25}$

\footnotetext{
20 The World Bank (2013), Afghanistan, Women's Role in Afghanistan's Future - Taking Stock of Achievements and Continued Challenges, available at: http://www-wds.worldbank.org/external/default/WDSContentServer/WDSP/IB/2014/04/22/000456286_20140422163258/Rendered/PDF/ ACS44740WP0Afg00Box382131B00PUBLIC0.pdf

${ }^{21}$ The Asia Foundation (March 5, 2014), Securing a Place for the Afghan Women in the Workplace, available at: http://asiafoundation.org/in-asia/ 2014/03/05/securing-a-place-for-afghan-women-in-the-workplace/

22 United Nations (2010), Ten-year Impact Study on Implementation of UN Security Council Resolution 1325 (2000) on Women, Peace and Security in Peacekeeping, available at: http://www.un.org/en/peacekeeping/documents/10year_impact_study_1325.pdf

${ }^{23}$ Medica Mondial (October 2007), Implementation of United Nations Security Council Resolution 1325 - Six Years On - Post-Bonn Gains and Gaps, available at: http://www.medicamondiale.org/fileadmin/redaktion/5 Service/Mediathek/Dokumente/English/Documentations_studies/ medica_mondiale_-_Report_on_Women_Peace_and_Security__October_2007.pdf

${ }^{24}$ UN WOMEN (October 2013), Women's inclusion in peace process critical for successful transition in Afghanistan, available at: http:// www.unwomen.org/en/news/stories/2013/10/john-hendra-speech-in-kabul-on-women-peace-and-security

${ }^{25}$ AWN interviews with female HPC and PPC members across Afghanistan, August-July 2014.
} 


\section{Public Perceptions About Women and Peace and Afghanistan}

\section{Figure 10: Awareness of the work of the Provincial Peace Councils - by gender}

Question: Are you aware of the work of the Provincial Peace Council (PPC) in our province? Do you know their work?

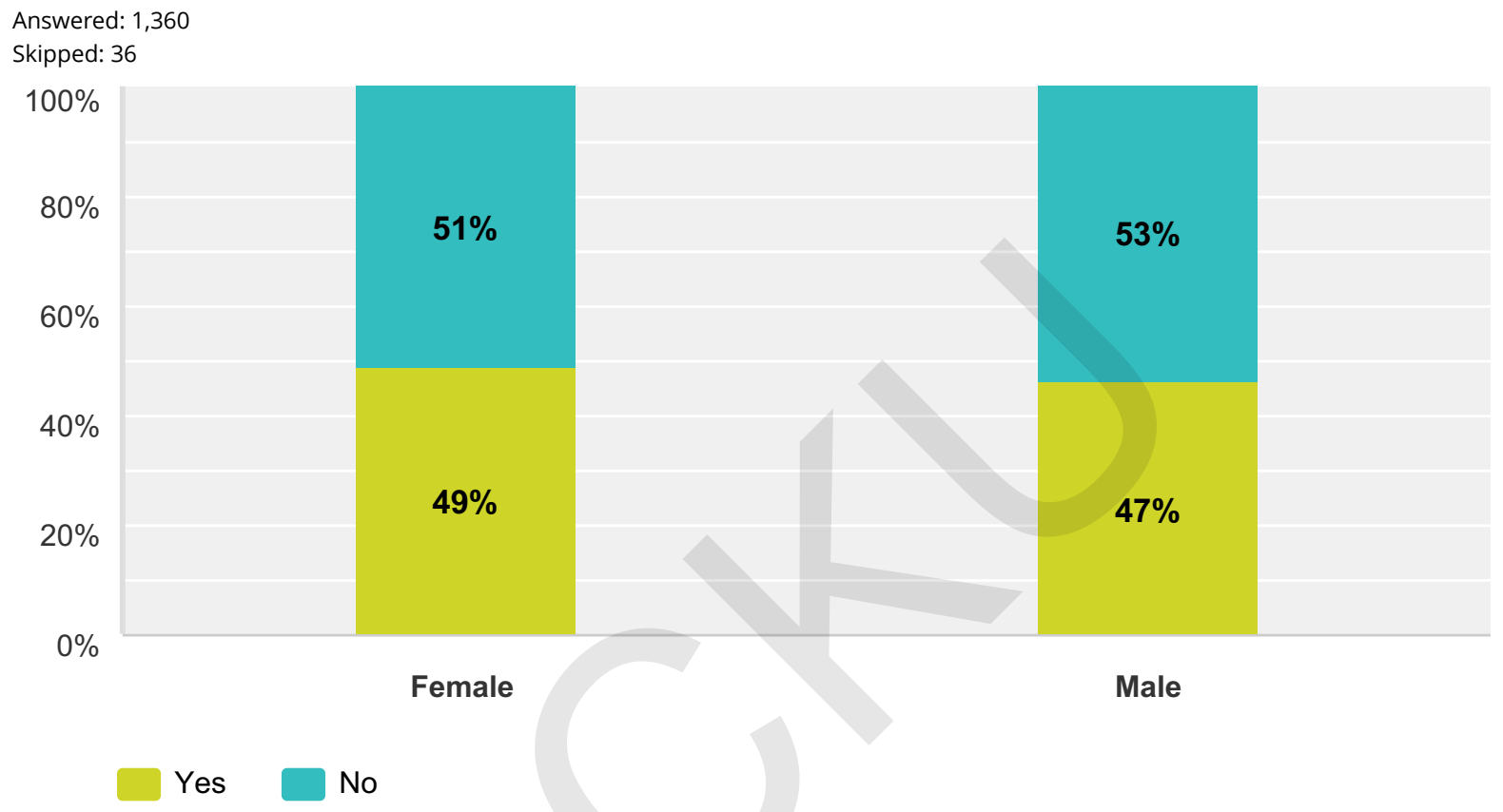

According to the survey findings, awareness about the activities of the PPCs remain limited, as 51 percent of the surveyed women and 53 percent of the surveyed men replied 'No' when asked if they were aware of the work of the PPC located in their province (Figure 10).

Regarding women's representation in the PPCs, more than 60 percent of the survey participants replied that they did not think the current quota for women PPC members is adequate and that more women should be present in the councils. The data also shows that more women than men tend to find the current quota unfair, since 65 percent of the female respondents found it unfair whereas 58 percent of the male respondents provided the same answer (Figure 11).

Similarly, the 72 percent of the total number of survey participants also believed that women should be present during peace negotiations. The remaining 28 percent thought that women had no place at the peace table. The majority of those that did not think it appropriate to have women at the peace table were men (Figure 12). 
Figure 11: Women's representation in the Provincial Peace Councils - general and by gender

Question: Currently, each Provincial Peace Council (PPC) has approximately 10 percent women members (2-4 out of 25-30 members are women). Do you think that this is a fair representation of women in the peace process of your province? Please select the option you agree with most.

Answered: 1,347

Skipped: 49
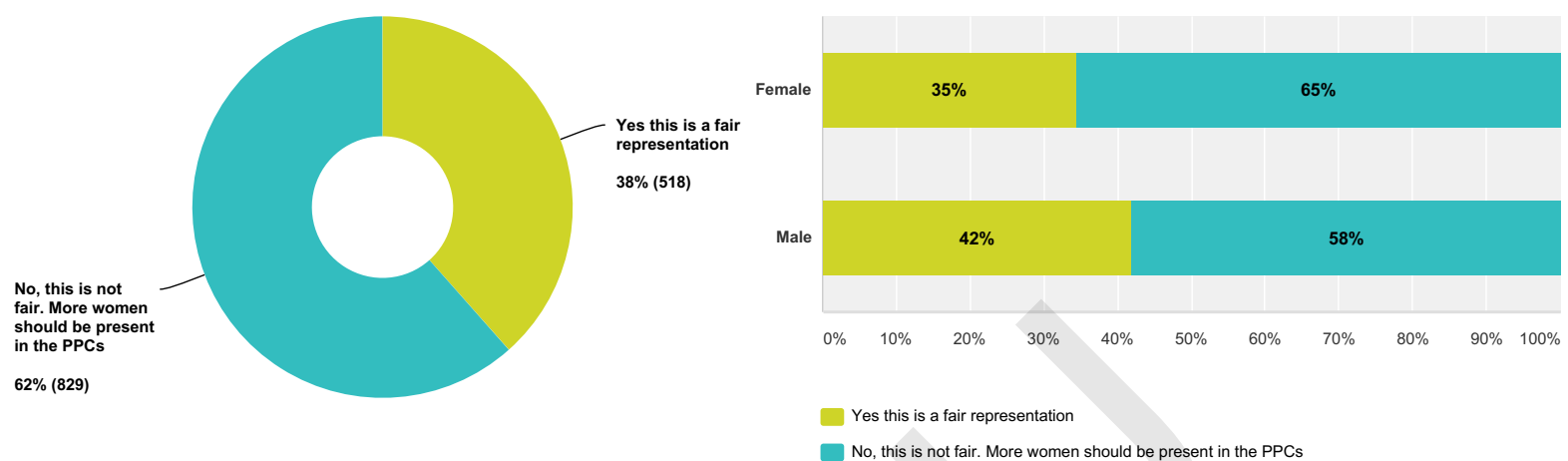

Figure 12: Perception about women's place at the peace table - general and by gender

Question: How do you feel about women's inclusion in the peace talks between the government of Afghanistan and the armed opposition? Should women be present at the peace table? Please select the answer you agree with most.

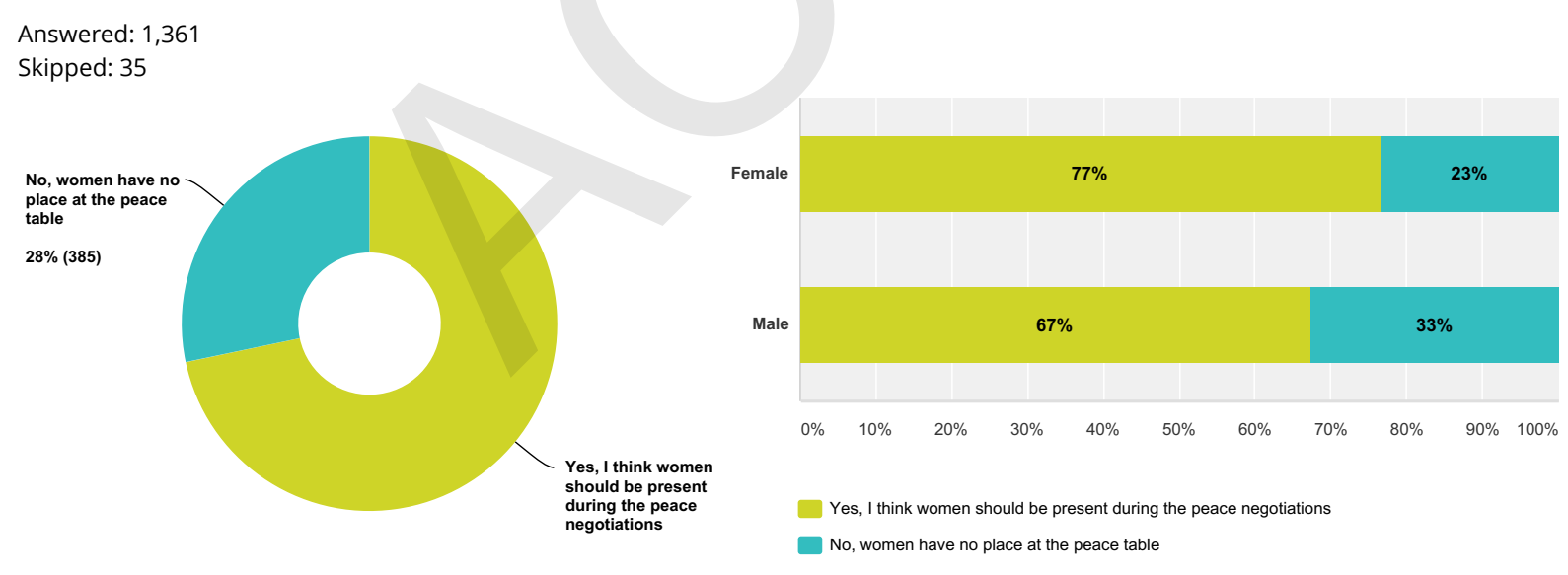


Figure 13: Women's rights being used as bargaining chip in peace negotiations - by gender

Question: Some people believe that peace negotiations between the government and the armed opposition will reverse some of the rights that women have obtained such as the right to vote, the right to go to school or work in public. What is your opinion about this perception? Please select the answer you agree with most.

Answered: 1,363

Skipped: 33

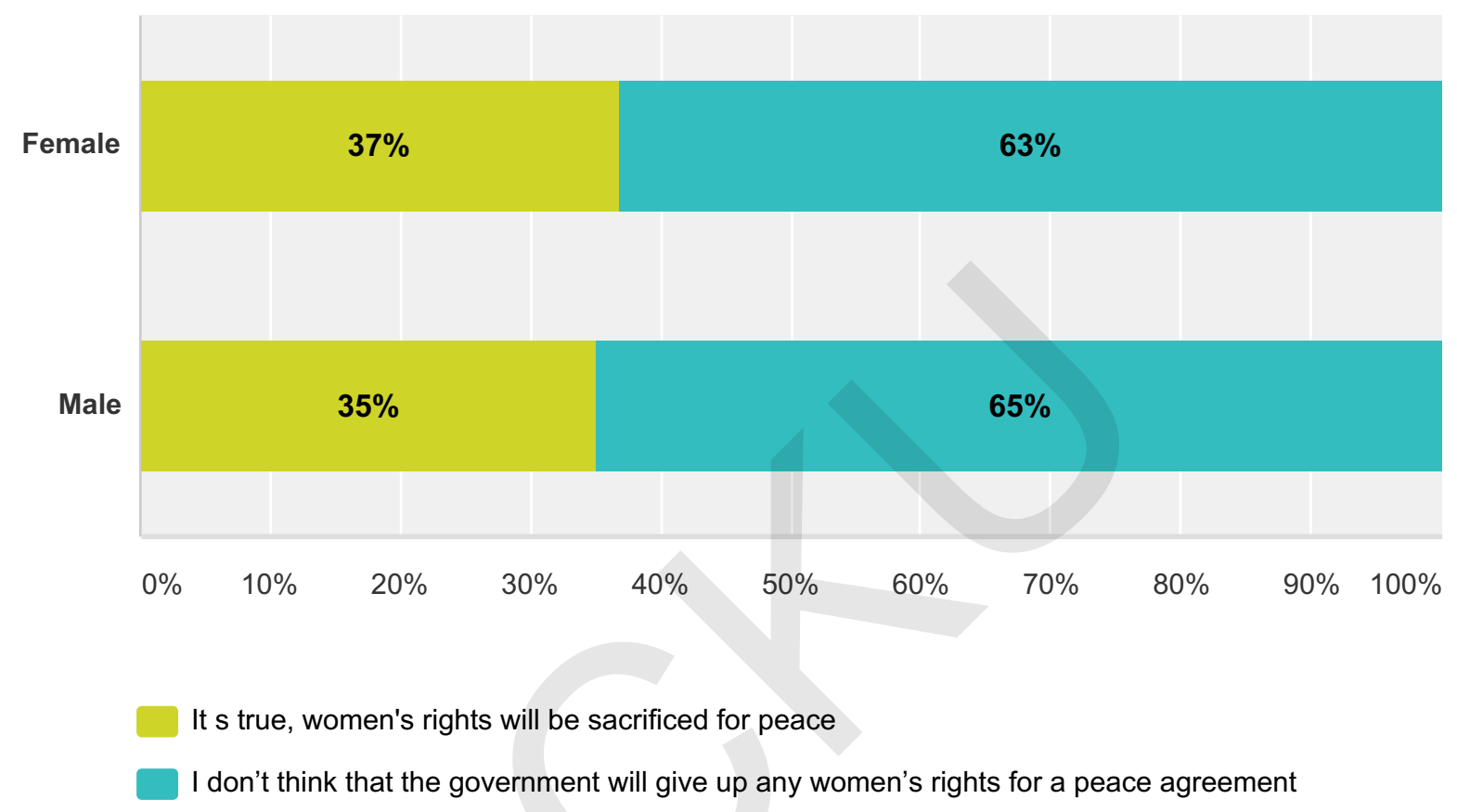

It appears, most Afghan men and women do not believe that the government of Afghanistan would trade away women's rights for peace (Figure 13). When asked about their reaction if the government did give up the rights of women to establish peace, 79 percent of the female and 71 percent of the male participants replied that the government does not have the right to give up women's rights (Figure 14). 


\section{Figure 14: Reactions to the possibility of giving up women's rights for peace - by gender}

Question: If the government of Afghanistan decided to sacrifice some of the civil rights that Afghan women have gained in the past thirteen years, such as the right to vote, the right to go to school or work in public, what would be your reaction? Please select the answer you agree with most.

Answered: 1,358

Skipped: 38

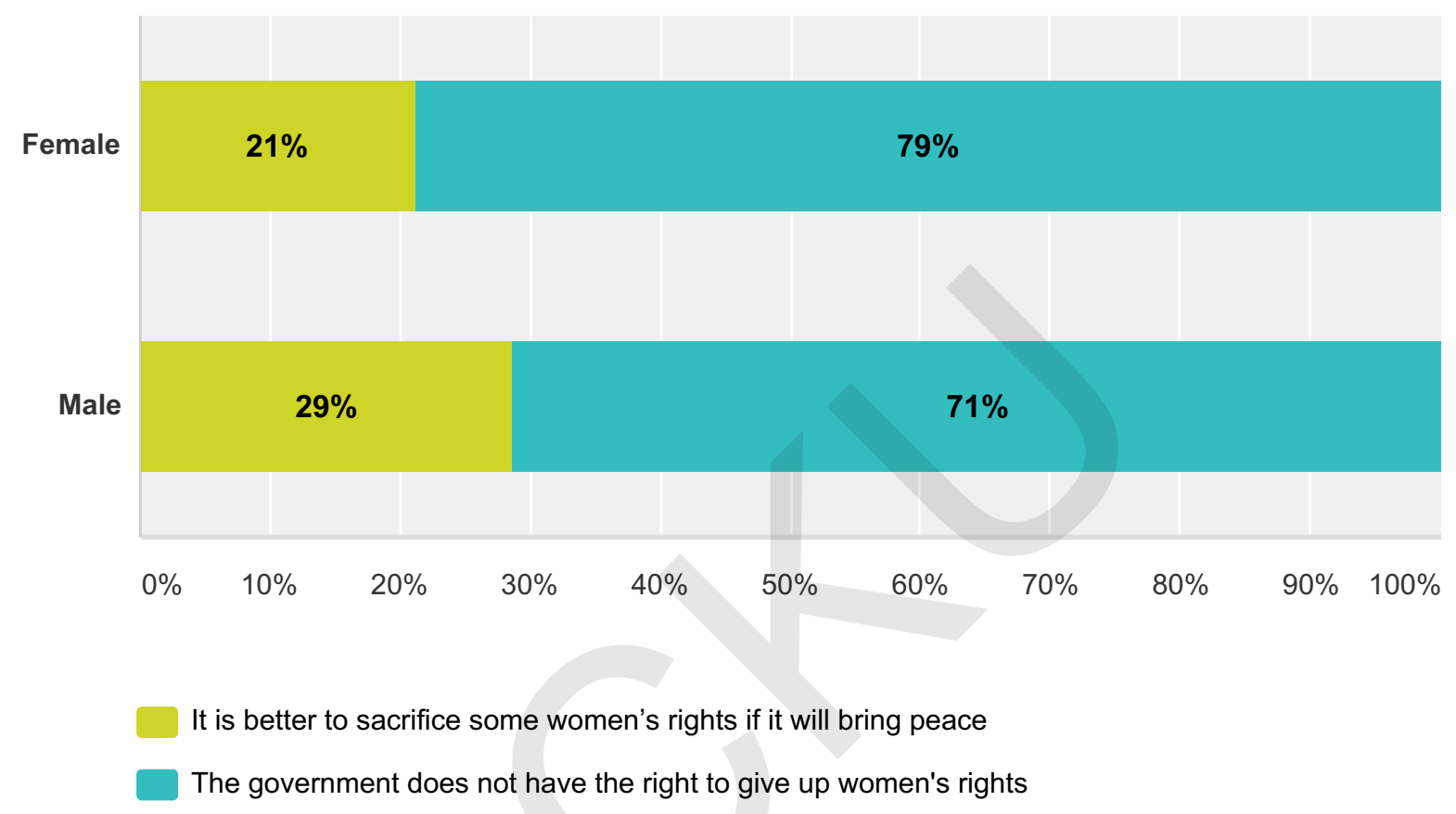




\section{Women's Legal and Social Protection}

\section{Access to Justice and Accountability in Afghanistan}

Although women's and girls' access to education and health services have improved significantly in the past thirteen years, much remains to be done to improve women's access to justice and inclusion in the country's governance structures. Weak state institutions, burdened with rampant corruption, are unable to implement the rule of law and enforce women's legal rights. Often, the more traditional segments of the Afghan society, which constitute the majority, perceive the promotion of women's rights and empowerment as a notion imposed by western countries. ${ }^{26}$

The Elimination of Violence Against Women (EVAW) law was enacted in Afghanistan through a presidential decree signed by president Karzai in 2009. Since then, the law has been implemented without the need of a parliamentary approval. Since its presidential enactment, Afghan women's rights activists have deliberately tried to keep the law from being reviewed in the parliament, fearing that it may be annulled by the conservative majority. In May 2013, the EVAW law was presented to the lower house of the parliament and was blocked by a majority of conservative legislators, who accused several of its articles of being un-Islamic whilst also encouraging female disobedience. Fortunately, the speaker of the parliament interrupted the session, referring the discussion to the Joint Commission and ended the debate, which prevented the parliament from nullifying the presidential decree. ${ }^{27}$ Today the EVAW law is still enforced in Afghanistan.

Through the EVAW law, violence against women was criminalized for the first time in the history of Afghanistan. While much progress has been achieved in the implementation of this law, female victims of violence still face barriers when pursuing their rights. According to a monitoring study by United Nations Assistance Mission in Afghanistan (UNAMA), only seven percent of the total registered Violence Against Women cases that had reached the police and prosecutors had gone through a judicial process using the EVAW law. ${ }^{28}$ This low number is mainly a result of mediation, which is often used by the police and justice officials as a way to solve domestic VAW cases informally. For example, cases that involve family disputes are often solved through mediation between the parties by the police or referred to informal dispute resolution mechanisms such as community Shuras. ${ }^{29}$

\footnotetext{
${ }^{26}$ AREU (September 2013).

${ }^{27}$ Afghan Analysts Network (May 18, 2013), Damage Avoided, for Now? The very short debate about the EVAW law, available at: https:// www.afghanistan-analysts.org/damage-avoided-for-now-the-very-short-debate-about-the-evaw-law/

28 UNAMA (December 2013), A Way to Go: An Update on Implementation of the Law on Elimination of Violence against Women in Afghanistan, available at: http://unama.unmissions.org/Portals/UNAMA/Documents/UNAMA\%20REPORT\%20on\%20EVAW\%20LAW_8\%20December \%202013.pdf

${ }^{29} \mathrm{~A}$ Shura is a consultative council at the community level made up of community elders.
} 
Mediation is frequently used as a dispute resolution method by police and prosecutors, since currently there are no sufficient social protection programs in Afghanistan for women that leave their homes as a result of domestic violence. ${ }^{30}$ This is problematic because cases that are solved through mediation or solved by informal mechanisms do not follow required justice procedures and undermine the implementation of the EVAW law. Mediated cases are often not followed up with by authorities to ensure the safety of the victims of violence after they agree to withdraw their complaints and women risk continued violence once they agree to return home as a result of mediation. Further, evidence suggests that most VAW cases still remain underreported, especially in rural Afghanistan where women are more reluctant to approach the police due to social rules and fear for reprisals. ${ }^{31}$

Currently, there are 150 female judges in Afghanistan. ${ }^{32}$ Similarly, 22 percent of its lawyers are women. ${ }^{33}$ Considering that there were no female judges and defense lawyers in the early 2000s, the representation of women in the judiciary has improved significantly in the past decade.

As of March 2014, the Afghan National Police (ANP) had a total of 152,123 personnel in its force. Women comprise only one percent of the ANP. ${ }^{34}$ Between the judiciary and security sector, women's participation in the judiciary has improved markedly, while women remain reluctant to join the security sector. This is mainly due to the many challenges that women face in the police force. Assault and sexual harassment of policewomen by male colleagues is a serious problem that remains to be addressed. ${ }^{35}$ Furthermore, police commanders at the provincial level are reluctant to recruit women in their police stations, and those that do recruit women often assign them menial tasks such as body searching, preparing tea or typing of documents. ${ }^{36}$

\footnotetext{
${ }^{30}$ Findings from AWN's monitoring project of EVAW Law implementation in Kabul province, November 2014.

31 UNAMA (December 2013).

32 Katzman, January 12, 2015.

${ }^{33}$ Data provided by the Afghanistan Independent Bar Association (AIBA).

${ }^{34}$ Special Inspector General for Afghanistan Reconstruction (SIGAR) (July 30, 2014), Quarterly Report to the United States Congress, available at: http://www.sigar.mil/pdf/quarterlyreports/2014-07-30qr.pdf

${ }^{35}$ Civil-Military Fusion Center (January 2012), Corruption in the Afghan National Security Forces, available at: https://www.cimicweb.org/ Documents/CFC\%20AFG\%20Security\%20Archive/CFC Afghanistan_Corruption-in-ANSF_Jan12.pdf

${ }^{36}$ Oxfam (September 2013), Women and the Afghan Police, available at: http://www.oxfam.org/sites/www.oxfam.org/files/bp173afghanistan-women-police-100913-summ-en_0.pdf
} 


\section{Public Perceptions About Women's Rights and Access to Justice}

Figure 15: Agreement on specific women's rights - by gender

Question: Which of the following statements do you agree with? Please select all that you agree with.

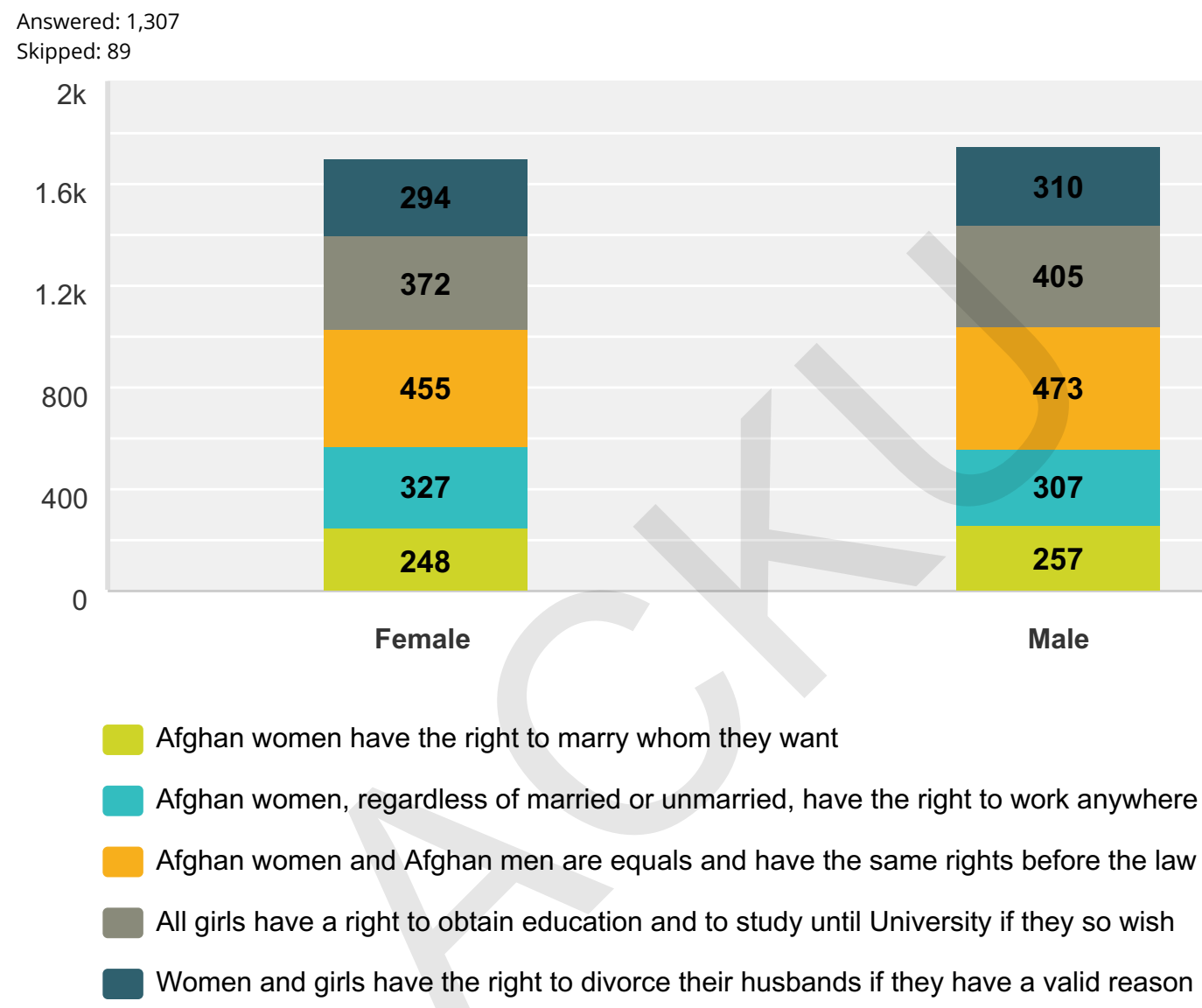

A total of 662 women and 734 men took part in the perception survey undertaken by AWN to inform this report (See Figure 1). Out of these, 455 women (68.7 percent) and 473 men (64.4 percent) agreed that all Afghan women and Afghan men are equals before the law. Similarly, 372 women (56.2 percent) and 405 men (61.2 percent) agreed that all girls have the right to complete their education until University if they so wish. These two statements were the most supported by the respondents. Women's rights such as being able to marry whom they want or the right to demand a divorce from their husbands if they had a valid reason were less supported (Figure 15). 
Figure 16: Social acceptability of women approaching police to file a complaint

Question: Under what circumstances do you think it is acceptable for a woman to go to the police and the prosecutor to file a complaint? Please select all options that you agree with (multiple choice).

Answered: 1,328

Skipped: 68

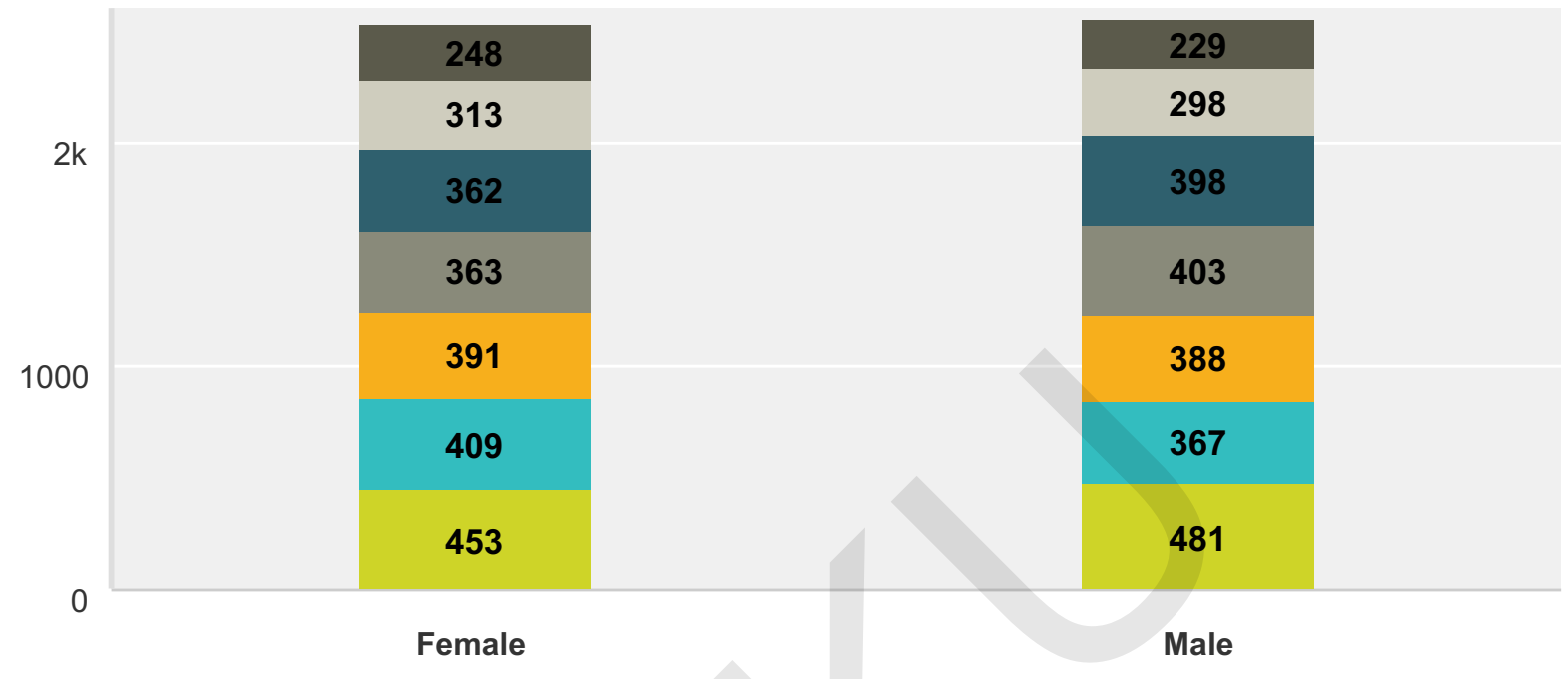

She has been physically abused (beaten) by a close family member

She is being married off by her family to someone she does not want to marry

She is being married off by her family although she is under the age of 16

She is being given away as baad

She wants to claim her inheritance which her relatives are denying her

She wants to go to school but her family will not let her

She wants to work outside the home but her family will not let her

In the Afghan society, it is often considered inappropriate for women to approach the police to seek justice or to file a complaint. To obtain a more nuanced understanding about the social acceptance of women approaching the police, the survey asked the participants under what circumstances it would be acceptable for women to go to the police or prosecutors. Out of the total survey population, 453 women (68.4 percent) and 481 men (65.5 percent) replied that it would be acceptable if women had been subject to physical abuse. 'She is being married of by her family to someone she does not want to marry' was the second most selected answer. The two least approved reasons to go to the police were if a woman 'wants to work outside the home and her family will not let her' or if 'she wants to g to school' against the wished of her family. 


\section{Figure 17: Most appropriate justice system}

Question: Which justice system is the most appropriate for a woman to approach when she has been wronged? Please select one of the two options.

Answered: 1,319

Skipped: 77

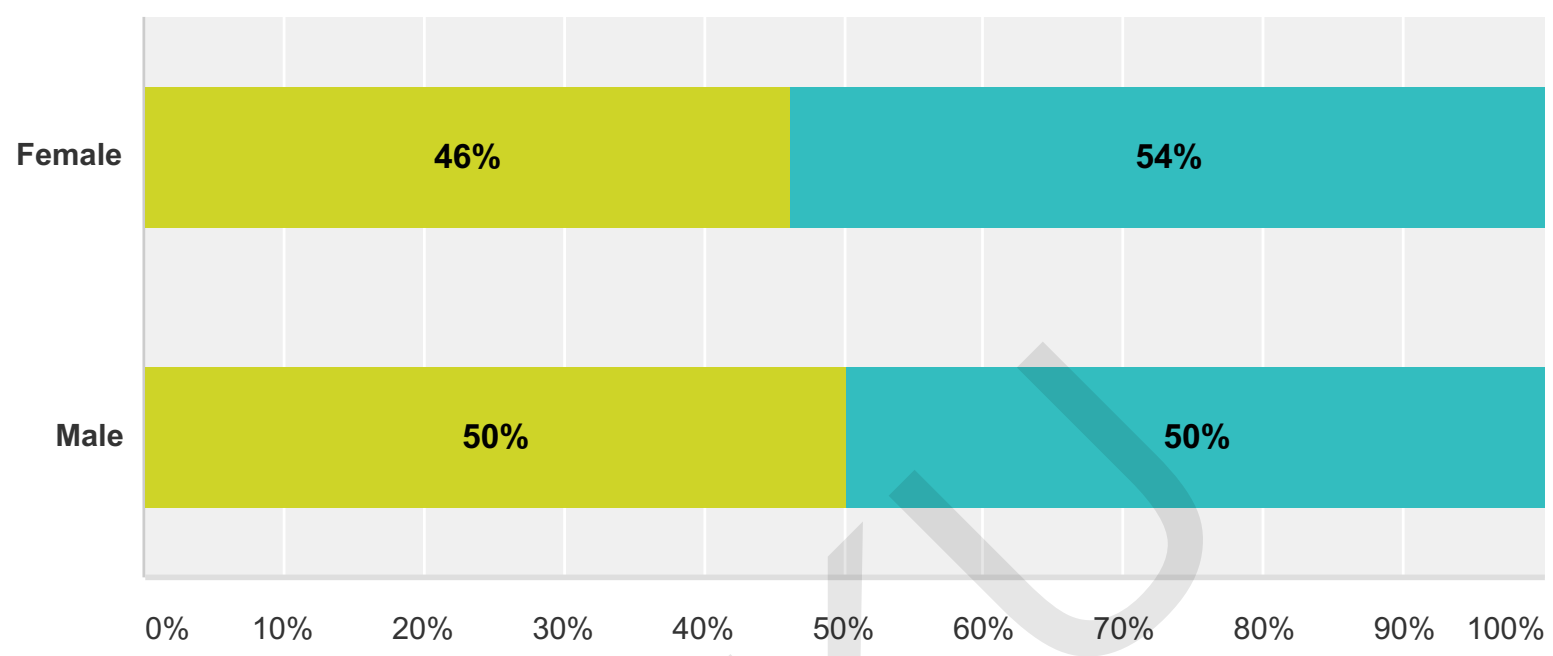

Community Shuras - village elders pass a verdict after listening to all parties

Formal justice system - through the ANP, prosecutors and the courts

When asked which justice system is more appropriate for a woman to approach when she has been wronged, half of the male respondents replied the formal justice system while the other half thought it more appropriate for women to approach community shares to access justice. However, in the case of the female survey participants, the majority (54 percent) replied that they thought the formal system is more appropriate (Figure 17). 
Figure 18: The importance of the the gender of the judge - by gender

Question: If you were accused of a crime and had trial at court, would you prefer a male or a female judge to pass the verdict? Please select one of the below options.

Answered: 1,328

Skipped: 68

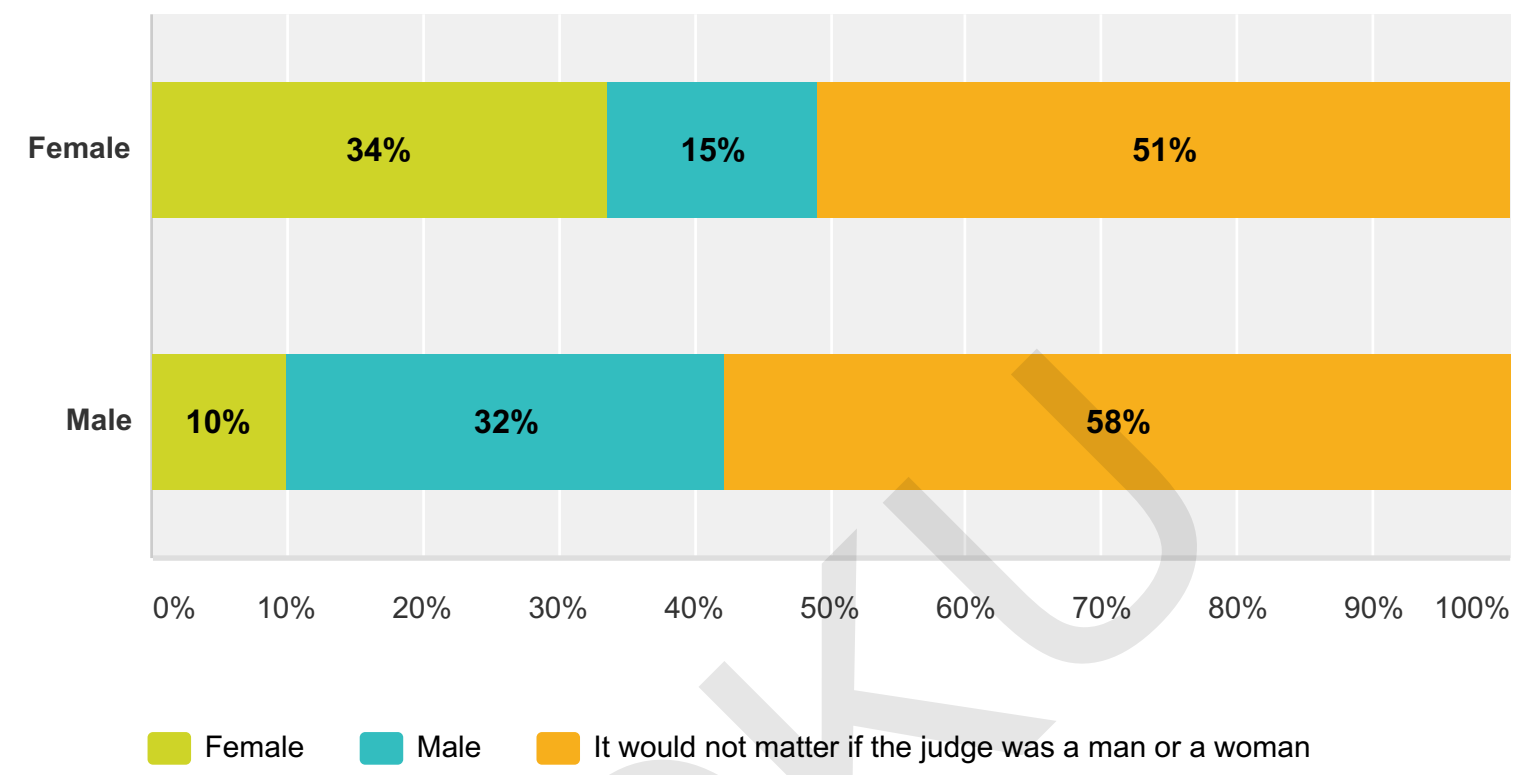

Findings from previous research by AWN has indicated that female judges often feel that there is a lack of trust in their abilities as justice officials, both by male colleagues and by the larger society. To test this notion, a question was included in the survey about the preference for the judge's gender, should they ever have a court case. Most survey participants replied that they did not think the gender of the judge would matter. However, 32 percent of the male respondents replied that they would prefer a male judge, while 34 percent of the female respondents stated that they would prefer a female judge (Figure 18). 


\section{Women's Social Protection and Participation in the Workforce}

Despite the improved access to education since 2001, many girls still remain out of school, not having enough opportunities to obtain an education and develop. Presently, 38 percent of the school aged children, most of which are girls, do not have access to education. Often, girls' schools get closed-down due to threats made by armed opposition groups that are against girls education. ${ }^{37}$ After nearly thirty years of conflict, the Afghan education system has suffered greatly and is unable to provide quality education. In 2001, after the fall of the Taliban regime, there were approximately 21.000 teachers available, which meant that the teacher student ratio was 240 students per teacher. ${ }^{38}$ The first national teacher training program was established in February 2003. ${ }^{39}$ Since then, the number of teachers has increased to 200,000 , of which 60,000 are female teachers. However, even with 200.000 teachers, the student-teacher ration remains relatively high with 41 students per teacher ( 8.2 million students divided by 200.000 teachers). ${ }^{40}$

The long years of conflict devastated not only the education system but also the health system of Afghanistan. By the time the Taliban regime had left power, the urgent need to build a healthcare system in the country was evident. In 2002, 75 percent of the births were taking place without the attendance of skilled health workers. The estimated maternal mortality rate had reached to the second highest in the world with 15,000 Afghan women dying each year. Correspondingly, the infant and under five mortality rates were estimated as 165 per 1.000 and 257 per 1.000 respectively. ${ }^{41}$

With financial support from major international donors such as the European Community, US Agency for International Development (USAID) and World Bank, significant recovery was enabled of the national health system through the Ministry of Public Health (MoPH). To address the poor health situation and the high mortality rate among Afghan women and children, a strategy to deliver a basic package of health services (BPHS) was developed in 2002. In 2005, a second program called essential package of hospital services (EPHS) was established to complement the BPHS. The purpose of the BPHS was to reach out to the Afghan population as a whole and to provide basic health services to the most vulnerable groups which were identified as women and

\footnotetext{
${ }^{37}$ UN Women (July 9, 2013), In Afghanistan, women and girls strive to get an education, available at: http://www.unwomen.org/en/news/stories/ 2013/7/afghani-women-strive-to-get-an-education

${ }^{38}$ The World Bank (September 2009), Expanding Access to Quality Education, available at: http://web.worldbank.org/WBSITE/EXTERNAL/ EXTABOUTUS/IDA/0, print:Y isCURL:Y contentMDK:21289161 menuPK:3266877 pagePK:51236175 piPK:437394 theSitePK:73154,00.html

39 UNICEF (February 2003), News Note: First national teacher training programme in Afghanistan gets underway, available at: http:// www.unicef.org/media/media_7316.html

${ }^{40}$ Institute of International Education (March 11, 2013), News from Afghanistan: Higher Education Needs the Support of International Partners, available at: http://www.iie.org/Blog/2013/March/News-from-Afghanistan

${ }^{41}$ United Nations (2002), Background Article - The Situation of Women in Afghanistan, available at: http://www.un.org/events/women/2002/ sit.htm
} 
children. ${ }^{42}$ In 2004, there where 116 hospitals, 544 Basic Health Centers, 547 Sub Health Centers in Afghanistan. According to statistics provided by the Ministry of Public Affairs, by 2013, the number of hospitals had increased to 149, while the number of Basic and Sub Health Centers had reached to 943 and 765 respectively. Similarly, the number doctors per ten thousand patients had increased from one to three. ${ }^{43}$

Furthermore, access to healthcare in rural and remote areas is more difficult than in urban Afghanistan. According to the National Risk and Vulnerability Assessment (NRVA) of 2011-2012, rural women are "Iess than half as likely to to be assisted by a skilled birth attendant". ${ }^{44}$

Only 19 percent (less than one in five women) of the working-age females are currently employed and able to generate an income. In comparison, roughly 80 percent of the workingage males are participating in the labor force. These figures indicate that there is a relatively large gender gap in the Afghan labor market, as for out of five women are out of work. The low rate of labor force participation among women is explained as being a consequence of cultural barriers that limit women's presence in public outside the home as well as traditional household responsibilities such as childcare. Among women with a tertiary education, however, the unemployment rat is relatively low. According to the NRVA 2011-2012, 78 percent of women with tertiary education are currently participating in the labor force of Afghanistan. ${ }^{45}$

Women's economic and social development is a key component of the NAPWA. According to the NAPWA, the government's strategy in this field is to create an enabling environment, which enables women to reach their full economic potential. To develop in the economic field, women's participation in other aspects of life, such as education and healthcare are essential. For example, without an adequate education, women will be unable to compete with men in the labor market. While women are active contributors to the Afghan economy through their participation in sectors such as agriculture, livestock management and handicrafts, their contributions often remain undervalued and underpaid. ${ }^{46}$

Some key impediments that currently prevent women's economic development include lack of literacy, inadequate business management skills, inability to reach local and international markets and lack of access to production equipment and facilities. ${ }^{47}$

\footnotetext{
${ }^{42}$ Afghanistan Mortality Survey (2010).

${ }^{43}$ Central Statistics Organization, Health Index, available at: http://cso.gov.af/en/page/demography-and-socile-statistics/social-statistics/ health-statistics

${ }^{44}$ Central Statistics Organization (2014), National Risk and Vulnerability Assessment 2011-12. Afghanistan Living Condition Survey, available at: http://www.af.undp.org/content/dam/afghanistan/docs/MDGs/NRVA\%20REPORT-rev-5\%202013.pdf

${ }^{45}$ Ibid.

${ }^{46}$ National Action Plan for the Women of Afghanistan (2007), available at: http://www.svri.org/Afghanistanpolicy.pdf

${ }^{47}$ AREU (November 2013), Women's Economic Empowerment in Afghanistan 2002-2012: Information Mapping and Situation Analysis, available at: http://areu.org.af/Uploads/EditionPdfs/Synthesis\%20Paper.pdf
} 


\section{Public Perceptions About Women's Access to Services}

Figure 19: Availability of schools

Question: Do you have enough schools for children in your community?

Answered: 1,331

Skipped: 65

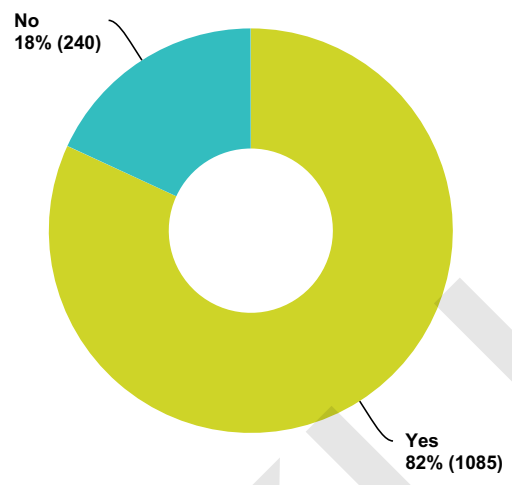

Figure 20: Average walking distance to schools

Question: On Average, how long does it take for children in your community to walk to school? Please select one of the (four) options.

Answered: 1,325

Skipped: 71

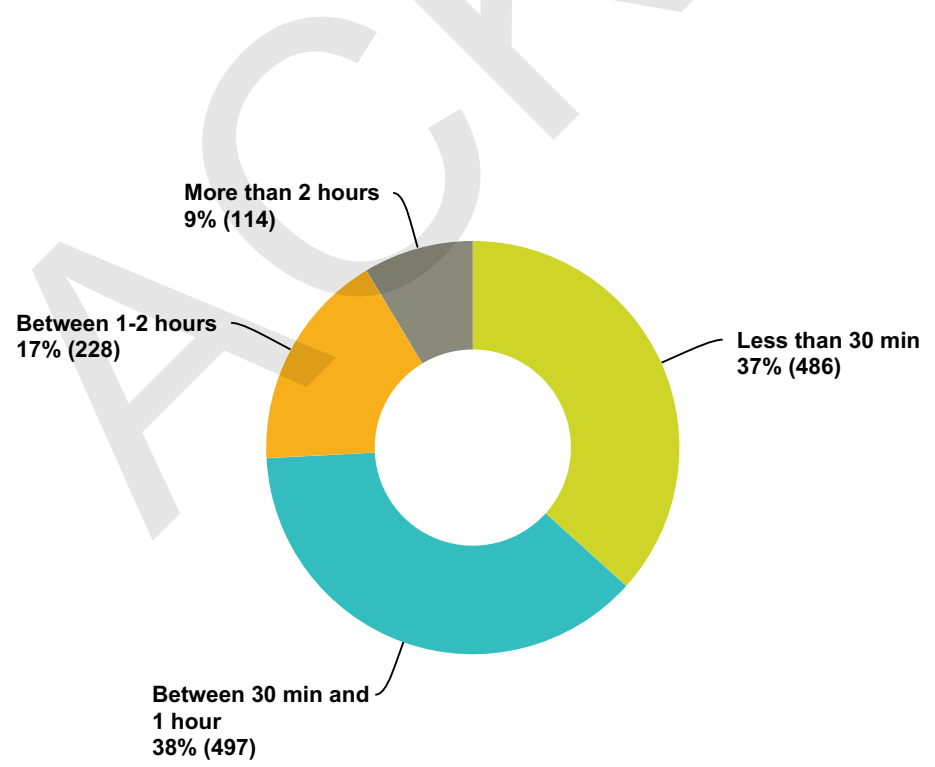

When asked about the availability of schools in the communities, 82 percent of the survey participants replied that they have enough schools (Figure 19). On average, 37 percent of the respondents stated that children in their community walk less than 37 minutes to school. Another 38 percent replied that the children in their community walk between 30 min and 1 hour. Those respondents that live 1-2 hours walking distance from the nearest school represented 17 percent. Only 9 percent of the respondents replied that children in their community walk more than 2 hours to go to school (Figure 20). 


\section{Figure 21: Availability of health facilities}

\section{Question: Do you have enough health facilities in your community?}

Answered: 1,325

Skipped: 71

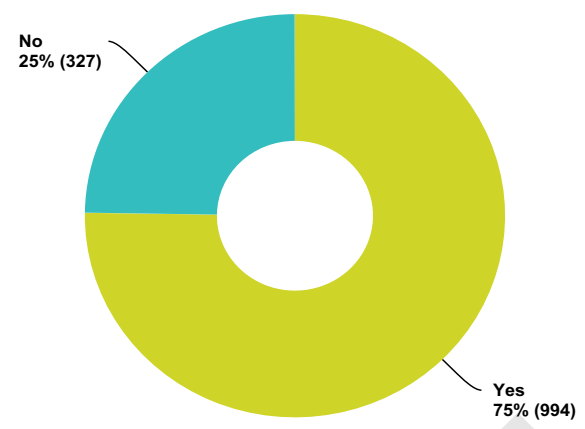

Figure 22: Average walking distance of health facilities

Question: How far do you have to walk to the closest health facility from your home? Please select one of the (four) options.

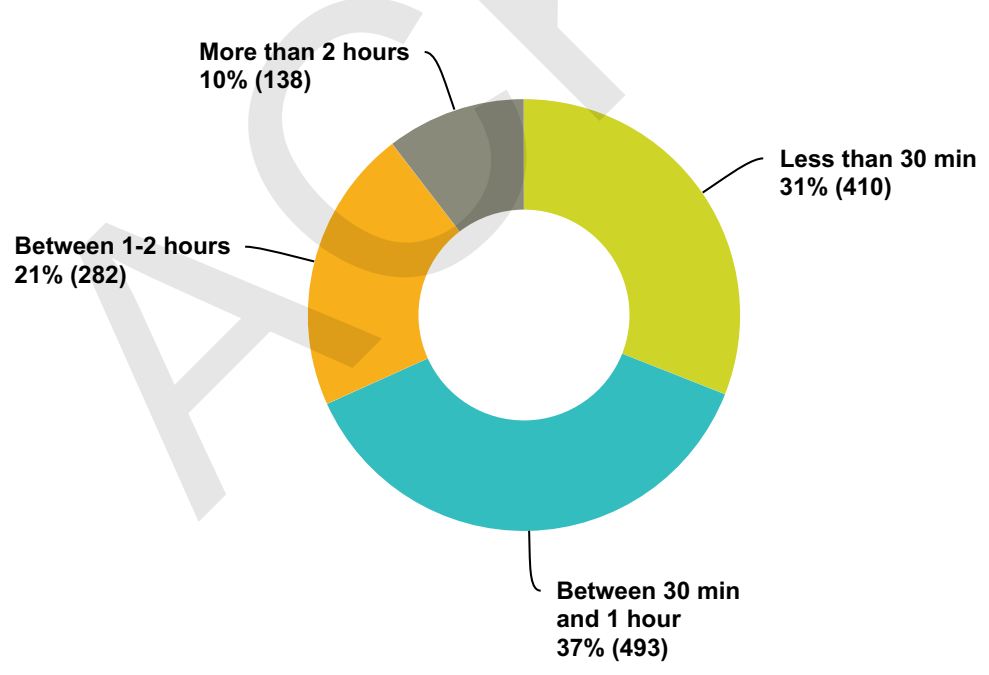

Regarding availability of health facilities, 75 percent of the survey participants replied that they had enough facilities in their communities (Figure 21). More than 30 percent replied that they live less than 30 min walking distance from the nearest health facility. Another 37 percent stated that they walk between 30 min and 1 hour while 21 percent walk 1-2 hours to nearest health facility. Only 10 percent of the survey participants replied that they walk more than 2 hours from their homes to the nearest health facility (Figure 22). Further, 73 percent of the survey population has access to female doctors in their community health facilities (Figure 23). 
Beijing+20 Afghanistan Civil Society Progress Report

\section{Figure 23: Availability of female doctors}

Question: Do you have female doctor(s) in your health facility?

Answered: 1,328

Skipped: 68

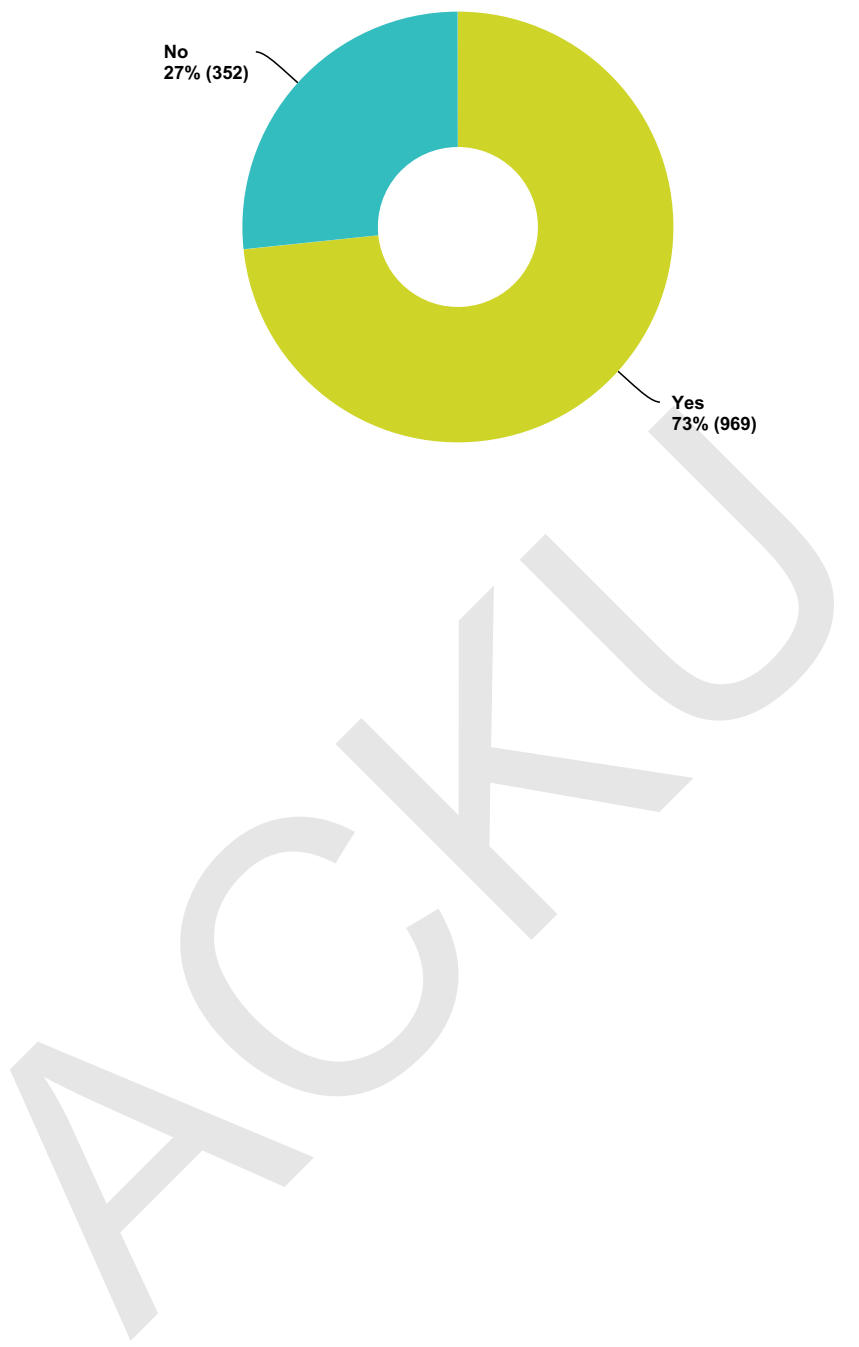




\section{Conclusion}

Today, 28 percent of the Lower House and 27 percent of the Upper House of the Parliament are held by women. Until recently, women also held more than 25 percent of the provincial peace council seats. At the local level, 30 percent of the Community Development Council members are women. In the public offices, women comprise 19 percent of the civil service. During the 2014 presidential elections, women embraced their democratic right as they represented 38 percent of the total voter turnout. These are tremendous steps towards the right direction, especially since a little more than thirteen years ago, women's access to public space and life was almost nonexistent.

There is no doubt that much has been achieved during the past decade in Afghanistan's recent history as a nation. Urged by the international community and donors, important commitments to ensure women's rights have been made repeatedly by the government of Afghanistan to ensure the inclusion of women at all stages of decision-making.

Although inspiring steps have been taken to encourage women's political participation and leadership in Afghanistan, conservative forces have at times put obstacles in the way of women's political empowerment. In May 2013, for example, such actors pushed for a revision of the electoral law, which reduced women's 25 percent quota of the provincial council seats to 20 percent. The justification for a decreased quota is not clear, especially since, as shown by AWN's recent survey, most Afghan women and men think that the quota system to ensure women's political participation should be preserved. Moreover, the recruitment of women to the civil service is too slow. While 19 percent is a notable progress from zero, it is still a long way from the targeted 30 percent as stipulated in the NAPWA. National strategies such as ANDS and the NAPWA continue to be poorly implemented at the local and subnational levels, mainly as a result of lack of political will, limited funding allocation and weak capacity among local institutions and individuals, responsible for the implementation.

The security situation, especially in rural Afghanistan, is another important challenge that needs to be addressed. The insecurity limits the mobility female politicians, which prevents them from campaigning in rural parts of the country.

Regarding women, peace and security, some notable developments include women's representation in the High Peace Council and its related Provincial Peace Councils. However, women's representation in these formal peace bodies has remained symbolic and has no real significance. Women members of the HPC and its PPCs often feel sidelined by their male peers, who often do not take women's insights and security needs into consideration. This is partially due to the low number of women representatives in these offices, however, the exclusion of women from the peace table also stems from the lack of political will to truly include women in the peace process as equal stakeholders. 
Weak state institutions, burdened with rampant corruption, are unable to implement the rule of law and enforce women's legal rights. The Elimination of Violence against Women (EVAW) law was enforced in Afghanistan through a presidential decree signed by president Karzai in 2009. Since then, its implementation has been impeded by corruption and culturally conservative mindsets that do not recognize women's equal rights before the law. A corrupt justice system has harmed the legitimacy of the formal justice system in the eyes of the Afghan people, which is indicated by the survey findings as close to half the survey respondents stated that they would prefer the informal (community Shura) justice system over the state courts.

Presently, 38 percent of the school aged children, most of which are girls, do not have access to education, while girls' schools continue getting closed-down due to threats by armed opposition groups. Since 2001, the number of teachers has increased has increased significantly, however, the student-teacher ratio still remains high.

Although access to healthcare, especially to reproductive health, has increased notably in the past decade, women in rural Afghanistan are still suffering from the lack of skilled birth attendants.

With regard to women's participation in the labor force, less than one in five working-age females are currently employed. The low rate of labor force participation among women is explained as being a consequence of persisting cultural barriers that limit women's presence in public space outside the home. 


\section{Recommendations}

\section{Women's Political Participation and Leadership}

\section{To the President of Afghanistan:}

1. Establish a Special Task Force, including Afghan women's rights organizations among other key stakeholders, to monitor the implementation of commitments to empower Afghan women and girls. Clear timelines, milestones and budgets should be made available.

\section{To the Government of Afghanistan:}

2. Ensure that women civil servants hold a minimum of 30 percent of the managerial positions in all ministerial offices.

3. Provide capacity development trainings for female management staff to build their confidence and management skill.

4. Increase the current 20 percent Provincial Council quota for women to 30 percent, especially since the quota system to ensure women's political participation is supported by the general population, as shown by the survey results of this report.

\section{To the International Community:}

5. Urge the Afghan ministries to strengthen the management skills of female civil servants through capacity building efforts.

\section{Women, Peace and Security}

\section{To the Government of Afghanistan and the High Peace Council:}

6. Increase the number of seats reserved for women in the provincial peace councils from 2-4 seats to at least 8-10, to ensure that women are not as easily sidelined in the councils.

7. Urge the High Peace Council to increase the number of their female members and to encourage their female members to be more active in the negotiation processes with the armed opposition.

8. Provide political and technical support to the female members of the High Peace Council and its provincial peace councils to allow them to meaningfully participate in peace process.

9. Put into effect the forthcoming National Action Plan (NAP) for the implementation of UNSCR 1325 without delay and monitor progress against key indicators as stated in the NAP. 
10. Earmark funding to ensure the implementation of the National Action Plan of UNSCR 1325.

11. Ensure the implementation of the National Action Plan of UNSCR 1325 at the subnational and local levels.

12. Comply with the UNSCR 1325 reporting requirements as outlined under CEDAW General Recommendation No. 30, with the full participation of Afghan civil society.

\section{To the International Community:}

13. Next to finalizing the National Action Plan on UNSCR 1325, issue a joint donor strategy to fund specific longer-term UNSCR 1325 implementation programs across Afghanistan.

14. Urge the government of Afghanistan and the High Peace Council to facilitate a more inclusive peace process by inviting women to the negotiation table with the armed opposition.

15. Increase your support to civil society organizations, especially to women's rights groups, by strengthening coordination efforts with the Afghan civil society.

\section{Women's Social and Legal Protection}

\section{To the Government of Afghanistan:}

16. Establish social protection and vocational programs to help female victims of violence maintain a livelihood after leaving their families as a result of domestic violence.

16. Urge the Afghan National Police to vigorously document mediated cases and to regularly follow up with them to make sure that female victims of violence that withdraw their complaints remain unharmed after the case is solved through mediation.

17. Invest in creating work opportunities for women by establishing 'women only' workspaces to encourage women's participation in the labor force while adhering to traditional values and social realities in Afghanistan.

\section{To the International Community:}

19. Encourage the Afghan government to invest in women's social and legal protection by funding programs that empower women victims of violence through education and economic means. 


\section{References}

Afghan Analysts Network (May 18, 2013), Damage Avoided, for Now? The very short debate about the EVAW law, available at: https://www.afghanistan-analysts.org/damage-avoided-for-now-the-veryshort-debate-about-the-evaw-law/

Afghan Public Health Institute (November 2011), Afghanistan Mortality Survey 2010, page 19, available at: http://dhsprogram.com/publications/publication-fr248-other-final-reports.cfm

Afghan Women's Six Point Petition (June 2014), available at: https://www.cordaid.org/media/ medialibrary/2014/06/Afghan Womens Six Point Petition 1.pdf

Amnesty International Report 1995 - Afghanistan, 1 January 1995, available at: http:// www.refworld.org/docid/3ae6a9fb18.html

AREU (September 2013), Women's Rights, Gender Equality, and Transition: Securing gains, moving forward, available at: http://www.areu.org.af/Uploads/EditionPdfs/women\%20and \%20Transition.pdf

AREU (November 2013), Women's Economic Empowerment in Afghanistan 2002-2012: Information Mapping and Situation Analysis, available at: http://areu.org.af/Uploads/EditionPdfs/Synthesis \%20Paper.pdf

BBC (November 16, 2014), Afghan woman MP survives car attack, available at: http://www.bbc.com/ news/world-asia-30073189

Central Statistics Organization, Health Index, available at: http://cso.gov.af/en/page/demographyand-socile-statistics/social-statistics/health-statistics

Central Statistics Organization (2014), National Risk and Vulnerability Assessment 2011-12. Afghanistan Living Condition Survey, available at: http://www.af.undp.org/content/dam/afghanistan/docs/ MDGs/NRVA\%20REPORT-rev-5\%202013.pdf

Civil-Military Fusion Center (January 2012), Corruption in the Afghan National Security Forces, available at: https://www.cimicweb.org/Documents/CFC\%20AFG\%20Security\%20Archive/ CFC_Afghanistan_Corruption-in-ANSF_Jan12.pdf

Cortright, D and Kirsten Wall (August 2012), Afghan Women Speak - Enhancing Security and Human Rights in Afghanistan, available at: http://kroc.nd.edu/sites/default/files/ Afghan Women Speak Report.pdf 
Institute of International Education (March 11, 2013), News from Afghanistan: Higher Education Needs the Support of International Partners, available at: http://www.iie.org/Blog/2013/March/News-fromAfghanistan

Katzman, K (November 30, 2012), Afghanistan: Politics, Elections and Government Performance, CRS Report for Congress, available at: http://www.au.af.mil/au/awc/awcgate/crs/rs21922.pdf

Katzman, K (January 12, 2015), Afghanistan: Politics, Elections and Government Performance, CRS Report for Congress, available at: https://www.fas.org/sgp/crs/row/RS21922.pdf

Medica Mondial (October 2007), Implementation of United Nations Security Council Resolution 1325 Six Years On - Post-Bonn Gains and Gaps, available at: http://www.medicamondiale.org/fileadmin/ redaktion/5_Service/Mediathek/Dokumente/English/Documentations_studies/medica_mondiale__Report_on_Women_Peace_and_Security_-_October_2007.pdf

National Action Plan for the Women of Afghanistan (2007), available at: http://www.svri.org/ Afghanistanpolicy.pdf

National Democratic Institute (June 16, 2014), Preliminary Statement of the National Democratic Institute's Election Mission for Afghanistan's 2014 Presidential Runoff Election, available at: https:// www.ndi.org/files/NDI-Afghanistan-2014-EOM-Runoff-Preliminary-Statement-FINAL.pdf

Oxfam (February 2011), High Stakes - Girls' Education in Afghanistan, available at: http:// www.oxfam.org/sites/www.oxfam.org/files/afghanistan-girls-education-022411.pdf

Oxfam (September 2013), Women and the Afghan Police, available at: http://www.oxfam.org/sites/ www.oxfam.org/files/bp173-afghanistan-women-police-100913-summ-en 0.pdf

Physicians for Human Rights (1998), The Taliban's War on Women, A Health and Human Rights Crisis in Afghanistan, available at: https://www.law.georgetown.edu/rossrights/docs/reports/taliban.pdf

Radio Free Europe / Radio Liberty (August 2014), Protections for Women Under Threat in Afghanistan, available at: http://www.rferl.org/content/afghanistan-women-gender-legislature-quota/ 25026221.html

Reuters (February 16, 2015), Bomb attack in eastern Afghanistan kills female politician, available at: http://uk.reuters.com/article/2015/02/16/uk-afghanistan-women-idUKKBNOLK1EB20150216

Special Inspector General for Afghanistan Reconstruction (SIGAR) (July 30, 2014), Quarterly Report to the United States Congress, available at: http://www.sigar.mil/pdf/quarterlyreports/

2014-07-30qr.pdf 
The Asia Foundation (March 5, 2014), Securing a Place for the Afghan Women in the Workplace, available at: http://asiafoundation.org/in-asia/2014/03/05/securing-a-place-for-afghan-women-inthe-workplace/

The Guardian (February 3, 2015), Afghan women protest at absence of female ministers in new cabinet, available at: http://www.theguardian.com/global-development/2015/feb/03/afghan-womenprotest-absence-female-ministers-new-cabinet

The Tokyo Declaration (July 8, 2012), available at: http://president.gov.af/Content/Media/ Documents/TokyoDeclaration-FinalEnglish87201218653461553325325.pdf

The World Bank (September 2009), Expanding Access to Quality Education, available at: http:// web.worldbank.org/WBSITE/EXTERNAL/EXTABOUTUS/IDA/0, print:Y isCURL:Y contentMDK: 21289161 menuPK:3266877 pagePK:51236175 piPK:437394 theSitePK:73154,00.html

The World Bank (2013), Afghanistan, Women's Role in Afghanistan's Future - Taking Stock of Achievements and Continued Challenges, available at: http://www-wds.worldbank.org/external/default/ WDSContentServer/WDSP/IB/2014/04/22/000456286 20140422163258/Rendered/PDF/ ACS44740WP0Afg00Box382131B00PUBLIC0.pdf

UNAMA (December 2013), A Way to Go: An Update on Implementation of the Law on Elimination of Violence against Women in Afghanistan, available at: http://unama.unmissions.org/Portals/UNAMA/ Documents/UNAMA\%20REPORT\%20on\%20EVAW\%20LAW 8\%20December\%202013.pdf

UN WOMEN (July 9, 2013), In Afghanistan, women and girls strive to get an education, available at: http://www.unwomen.org/en/news/stories/2013/7/afghani-women-strive-to-get-an-education

UN WOMEN (October 2013), Women's inclusion in peace process critical for successful transition in Afghanistan, available at: http://www.unwomen.org/en/news/stories/2013/10/john-hendraspeech-in-kabul-on-women-peace-and-security

UNICEF (February 2003), News Note: First national teacher training programme in Afghanistan gets underway, available at: http://www.unicef.org/media/media 7316.html

United Nations (2002), Background Article - The Situation of Women in Afghanistan, available at: http:// www.un.org/events/women/2002/sit.htm

United Nations (2010), Ten-year Impact Study on Implementation of UN Security Council Resolution 1325 (2000) on Women, Peace and Security in Peacekeeping, available at: http://www.un.org/en/ peacekeeping/documents/10year impact study 1325.pdf 